\title{
Loss of apical monocilia on collecting duct principal cells impairs ATP secretion across the apical cell surface and ATP-dependent and flow-induced calcium signals
}

\author{
Michael B. Hovater • Dragos Olteanu • \\ Elizabeth L. Hanson • Nai-Lin Cheng • Brian Siroky • \\ Attila Fintha • Peter Komlosi • Wen Liu • \\ Lisa M. Satlin • P. Darwin Bell • Bradley K. Yoder • \\ Erik M. Schwiebert
}

Received: 24 July 2006 / Accepted: 1 November 2006 / Published online: 13 November 2007

(C) Springer Science + Business Media B.V. 2007

\begin{abstract}
Renal epithelial cells release ATP constitutively under basal conditions and release higher quantities of
\end{abstract}

M. B. Hovater $\cdot$ D. Olteanu $\cdot$ E. L. Hanson · N.-L. Cheng •

B. Siroky E. M. Schwiebert

Department of Physiology and Biophysics,

University of Alabama at Birmingham,

1918 University Blvd.,

Birmingham, AL 35294-0005, USA

B. K. Yoder • E. M. Schwiebert

Department of Cell Biology,

University of Alabama at Birmingham,

1918 University Blvd.,

Birmingham, AL 35294-0005, USA

A. Fintha $\cdot$ P. Komlosi • P. D. Bell

Department of Medicine, University of Alabama at Birmingham, 1918 University Blvd.,

Birmingham, AL 35294-0005, USA

B. Siroky • P. Komlosi • P. D. Bell • B. K. Yoder •

E. M. Schwiebert

The Recessive PKD Translational and Research Core Centers,

University of Alabama at Birmingham,

1918 University Blvd.,

Birmingham, AL 35294-0005, USA

W. Liu $\cdot$ L. M. Satlin

Departments of Pediatrics and Medicine,

Mount Sinai School of Medicine,

New York, NY 10029-6574, USA

E. M. Schwiebert $(\bowtie)$

Departments of Physiology and Biophysics and of Cell Biology,

University of Alabama at Birmingham,

MCLM 740, 1918 University Blvd.,

Birmingham, AL 35294-0005, USA

e-mail: eschwiebert@physiology.uab.edu purine nucleotide in response to stimuli. ATP filtered at the glomerulus, secreted by epithelial cells along the nephron, and released serosally by macula densa cells for feedback signaling to afferent arterioles within the glomerulus has important physiological signaling roles within kidneys. In autosomal recessive polycystic kidney disease (ARPKD) mice and humans, collecting duct epithelial cells lack an apical central cilium or express dysfunctional proteins within that monocilium. Collecting duct principal cells derived from an Oak Ridge polycystic kidney (orpk ${ }^{T g 737}$ ) mouse model of ARPKD lack a well-formed apical central cilium, thought to be a sensory organelle. We compared these cells grown as polarized cell monolayers on permeable supports to the same cells where the apical monocilium was genetically rescued with the wild-type $\operatorname{Tg} 737$ gene that encodes Polaris, a protein essential to cilia formation. Constitutive ATP release under basal conditions was low and not different in mutant versus rescued monolayers. However, genetically rescued principal cell monolayers released ATP three- to fivefold more robustly in response to ionomycin. Principal cell monolayers with fully formed apical monocilia responded three- to fivefold greater to hypotonicity than mutant monolayers lacking monocilia. In support of the idea that monocilia are sensory organelles, intentionally harsh pipetting of medium directly onto the center of the monolayer induced ATP release in genetically rescued monolayers that possessed apical monocilia. Mechanical stimulation was much less effective, however, on mutant orpk collecting duct principal cell monolayers that lacked apical central monocilia. Our data also show that an increase in cytosolic free $\mathrm{Ca}^{2+}$ primes the ATP pool that is released in response to mechanical stimuli. It also appears 
that hypotonic cell swelling and mechanical pipetting stimuli trigger release of a common ATP pool. Ciliumcompetent monolayers responded to flow with an increase in cell $\mathrm{Ca}^{2+}$ derived from both extracellular and intracellular stores. This flow-induced $\mathrm{Ca}^{2+}$ signal was less robust in cilium-deficient monolayers. Flow-induced $\mathrm{Ca}^{2+}$ signals in both preparations were attenuated by extracellular gadolinium and by extracellular apyrase, an ATPase/ADPase. Taken together, these data suggest that apical monocilia are sensory organelles and that their presence in the apical membrane facilitates the formation of a mature ATP secretion apparatus responsive to chemical, osmotic, and mechanical stimuli. The cilium and autocrine ATP signaling appear to work in concert to control cell $\mathrm{Ca}^{2+}$. Loss of a cilium-dedicated autocrine purinergic signaling system may be a critical underlying etiology for ARPKD and may lead to disinhibition and/or upregulation of multiple sodium $\left(\mathrm{Na}^{+}\right)$ absorptive mechanisms and a resultant severe hypertensive phenotype in ARPKD and, possibly, other diseases.

Keywords ATP secretion - Nucleotide secretion ·

Purinergic signaling $\cdot$ Kidney $\cdot$ Renal collecting duct $\cdot$ Cilia

\begin{tabular}{|c|c|}
\hline \multicolumn{2}{|c|}{ Abbreviations } \\
\hline ATP & adenosine 5 '-triphosphate \\
\hline $\mathrm{Ca}^{2+}$ & calcium \\
\hline orpk & Oak Ridge polycystic kidney \\
\hline ARPKD & $\begin{array}{l}\text { autosomal recessive polycystic } \\
\text { kidney disease }\end{array}$ \\
\hline $\mathrm{Na}^{+}$ & sodium \\
\hline $\operatorname{Tg} 737$ gene & Polaris gene \\
\hline MDCK & Madin-Darby canine kidney \\
\hline $\mathrm{CCD}$ & cortical collecting duct \\
\hline $\mathrm{PC}$ & principal cell \\
\hline ER & endoplasmic reticulum \\
\hline ALU & arbitrary light units \\
\hline TRP & transient receptor potential \\
\hline RVD & regulatory volume decrease \\
\hline $\mathrm{K}^{+}$ & potassium \\
\hline $\mathrm{Cl}^{-}$ & chloride \\
\hline DIDS & 4,4'-diisothiocyanato-stilbene-2, \\
\hline $\mathrm{NO}$ & $\begin{array}{l}\text { 2'-disulfonic acid } \\
\text { nitric oxide }\end{array}$ \\
\hline
\end{tabular}

\section{Introduction}

Monociliated ductal epithelial cells are receiving much attention due to their remodeling in polycystic kidney diseases, role in other cystic diseases of the kidney and other tissues, and in sensory physiology [1-12]. Cilia and flagella from lower organisms have important roles in sensory physiology in response to flow, touch, chemical and osmotic stimuli $[1-5,15,16]$. MDCK cells and other cell and tissue models of the renal collecting duct have been essential in characterizing cilium-derived cell calcium $\left(\mathrm{Ca}^{2+}\right)$ signals [17-30]. It appears likely that this ciliumaffected $\mathrm{Ca}^{2+}$ signal is derived from $\mathrm{Ca}^{2+}$ entry from extracellular stores and $\mathrm{Ca}^{2+}$ release from intracellular stores; the latter, perhaps, an ER cisternae near the basal body immediately beneath the monocilium [17-30]. Previously thought to be a vestigial organelle [1-5] or morphological marker for the cortical collecting duct (CCD) principal cell (PC) [31], the apical central monocilium is likely a sensor for ductal epithelia [5].

Recently, our laboratory has shown that epithelial sodium channel $(\mathrm{ENaC})$-mediated sodium $\left(\mathrm{Na}^{+}\right)$absorption is upregulated in mutant cilium-deficient orpk CCD PC monolayers versus genetically rescued cilium-competent controls [32]. ENaC activity is present under open-circuit voltage and short-circuit current measurements in rescued cell monolayers with a well-formed cilium, but the electrical signals were three- to sixfold less than mutant monolayers [32]. One of our working hypotheses is that an inhibitory signal is lost (when the monocilium is not well formed) that is responsible for tonic attenuation of $\mathrm{ENaC}$ function [32]. Indeed, flow-induced $\mathrm{Ca}^{2+}$ signals have been shown recently by Praetorius and Leipziger not to be due to the cilium of MDCK cells per se but to autocrine ATP signaling that is stimulated by pressure pulses and responsible for $\mathrm{Ca}^{2+}$ spark and wave signal formation [33]. Immature MDCK cells without discernible cilia and mature MDCK cells with cilia responded similarly [33]. Alternatively, Satlin and coworkers have compelling data that monocilia do confer flow-based $\mathrm{Ca}^{2+}$ signals in isolated perfused CCDs from control mice versus mutant $\operatorname{Tg} 737^{\text {orpk }}$ mice [20]. In multiple different preparations from tissue to renal epithelia to heterologous cells, flow-induced $\mathrm{Ca}^{2+}$ signals have been observed [17-30]. However, the concept that an autacoid might mediate these cilium-specific effects has not been addressed.

Herein, we show that the fully formed monocilium does confer a more robust $\mathrm{Ca}^{2+}$ signal in rescued cell monolayers versus mutant cell monolayers that are deficient in wellformed cilia. This finding agrees with the majority of the literature examining this phenotype [17-30]. However and more importantly, we show that stimulated or regulated ATP release is impaired when the monocilium is malformed. Ionomycin-, hypotonicity-, and mechanically induced ATP release are more robust in cilium-competent monolayers versus cilium-deficient monolayers. Varying the order of stimuli also revealed that cell $\mathrm{Ca}^{2+}$ influences the mechanically induced secreted ATP pool and that hypotonic cell swelling and other mechanical stimuli trigger the release of the same ATP pool. Finally, the flow-induced 
$\mathrm{Ca}^{2+}$ signal in this cell model requires autocrine ATP release and signaling, as it was blocked by the ATPase/ ADPase scavenger, apyrase. These data may reconcile the different conclusions within the Praetorius and Leipziger study [33] and the study of Satlin and coworkers [20]. To our knowledge, this is the first report linking the sensory apical central and nonmotile cilium to ATP secretion.

\section{Materials and methods}

Cell culture The collecting duct principal cells derived from an Oak Ridge polycystic kidney (orpk) mouse model of autosomal recessive polycystic kidney disease (ARPKD) and the genetically rescued cells with the wild-type orpk $^{T g 737}$ gene were a generous gift from Dr. Bradley Yoder (University of Alabama at Birmingham). The "mutant 1" cell clone (94D pcDNA 3.1 cells), the "rescued 1" cell clone (94D BAP737-1 cells), and the "rescued 2" cell clone (94D 737-2 cells) were handled identically and were grown under G418 selection on $6.5-\mathrm{mm}$ diameter (Corning Costar) or 12-mm diameter filter supports (Millicell CM) and bathed in Dulbecco's modified Eagle's medium nutrient mixture F-12 HAM with L-glutamine and $15 \mathrm{mM}$ hydroxyethylpiperazine ethanesulfonic acid (HEPES) (Sigma) [32]. This medium was supplemented with $5 \%$ fetal bovine serum (FBS) and contained (per $1,000 \mathrm{ml})$ dexamethasone $(100 \mu \mathrm{l} / \mathrm{l}$ of $2 \mathrm{mg} / \mathrm{ml}$ stock $)$, interferon- $\gamma(25 \mu \mathrm{l}$ of $800 \mathrm{U} / \mu \mathrm{l}$ stock $)$, T3 $(10 \mu \mathrm{l} / \mathrm{l}$ of $13 \mathrm{mg} / \mathrm{ml}$ stock), G418 (500 $\mu \mathrm{l}$ of $400 \mu \mathrm{g} / \mathrm{ul}$ stock), penicillin-streptomycin (10 $\mathrm{ml}$ of $100 \mathrm{X}$ stock), and ITS $(10 \mathrm{ml}$ of $0.5 \mathrm{mg} / \mathrm{ml}$ insulin transferrin selenium concentrated stocks). The cells continued to be bathed on both sides of the filter until a monolayer tight to fluid formed. Measurement of the resistance of the filters was used as an indicator of the formation of a mature monolayer. Once the monolayers were formed for at least $12 \mathrm{~h}$, the cells were then acceptable for the experimental assay.

In addition to these original clones developed in the Yoder laboratory, we also generated two new clonal lines from the original 94D mixed mutant CCD cell cultures, namely "mutant 2" and "mutant 3." The only difference between these two subsequent clones and the original "mutant 1 " clone is the fact that the "mutant 1 " clone is stably transfected with an "empty" pcDNA 3.1 vector that confers G418 resistance. "Mutant 2," "mutant 3," and the mixed mutant cultures are grown in a medium without G418. We also studied a "rescued B2" clone that was stably transfected and rescued with the wild-type $\operatorname{Tg} 737$ gene but we derived from a different mutant CCD originally, 94E. The generation of these additional clones was described in a previous publication [32].
Bioluminescence detection of ATP released from epithelial monolayers In every assay performed, there was an initial basal ATP measurement followed by subsequent ATP measurements in response to different stimuli added in different sequences. ATP release assays were performed mainly on well-polarized cell monolayers grown in clear polyester $6.5-\mathrm{mm}$ diameter filter supports. Mutant versus rescued cell monolayers were studied side by side in each ATP release protocol. The use of luciferase-luciferin to indirectly measure the ATP concentration has been published previously in detail [34]. Every drug prior to experimentation was tested to ensure that they did not interfere with the luciferase enzyme activity [34-37]. There was also no change in cell viability with any of these maneuvers as has also been reported previously [34-37]. Each experiment began with a basal ATP measurement or the addition of Opti-MEM I medium (GIBCO-BRL) with $1 \mathrm{mg} / \mathrm{ml}$ luciferase-luciferin reagent (Sigma) being added to the apical or basolateral side of the filter's monolayer. Basolateral ATP release was negligible; therefore, all data reported are apical or luminal ATP secretion. Basal levels of ATP release were measured for $6 \mathrm{~min}$ in 15-s, nonintegrated photon collection periods in a TD-20/20 Luminometer (Turner Designs) [34-37]. In different orders of addition, we used the following stimuli: (1) ionomycin $(2 \mu \mathrm{M})$ (to increase the intracellular calcium concentration), (2) distilled water with $1 \mathrm{mg} / \mathrm{ml}$ luciferase-luciferin (to dilute the osmotic strength of the Opti-MEM I medium), and (3) intentionally harsh pipetting in the center of the apical surface of the cell monolayer (to induce a mechanical stimulus on the apical membrane). Normally, addition of drug or distilled water (or the same volume of medium as a volume addition control) is performed or dispensed very slowly along the wall of the plastic support that holds the permeable filter so as not to disrupt the tight, confluent monolayer. Therefore, by quickly pipetting the medium up and down onto the monolayers, a mechanical stimulation is induced. Luminescence was measured for 6 min after each stimulus. All experiments ended with the addition of hexokinase to eliminate any ATP left in the medium. All assays were performed at room temperature.

Fura-2/AM imaging of cytosolic free calcium in a cell monolayer-based perfusion system Fura-2/AM imaging was performed as described previously [38-40]. However, to remain faithful to the study of polarized cell monolayers, we designed a cell monolayer-based perfusion chamber system where $12-\mathrm{mm}$ diameter Snapwell Transwell filter supports are inserted into a homemade perfusion chamber designed to accommodate this special filter support. Apical and basolateral perfusion are then performed separately through independent injection ports and separate ejection ports are subjected to vacuum. Response to changes in 
apical flow from $1 \mathrm{ml} / \mathrm{min}$ (a "slow" flow) to $5 \mathrm{ml} / \mathrm{min}$ ("high" flow) were performed to induce a flow-induced $\mathrm{Ca}^{2+}$ transient akin to that observed by many other laboratories. We assessed mutant and rescued cell monolayers in parallel during all protocols. We also assessed the flowinduced $\mathrm{Ca}^{2+}$ transient signal in the absence of apical extracellular $\mathrm{Ca}^{2+}$ and in the presence of gadolinium chloride and apyrase. It was not possible to calibrate the Fura-2 fluorescence signal to real free cytosolic $\mathrm{Ca}^{2+}$ values because of ionomycin contamination of the flow chamber. As such, fluorescence ratio values are shown. We give estimates of what the free $\mathrm{Ca}^{2+}$ may be based on previous calibrations of the same cells grown as nonpolarized cells.

Materials All reagents and drugs were purchased from Sigma. Larger $12-\mathrm{mm}$ diameter filter supports were obtained from Millipore. Smaller 6.5-mm diameter filter supports were obtained from Corning Costar. It should be noted that we are using less luciferase:luciferin detection reagent than in past studies [34-37].

\section{Results}

Basal ATP release or secretion is not different between mutant and rescued CCD PC monolayers Basolateral ATP release was near background and was negligible in both mutant and rescued cell monolayers. This result does not mean that ATP is not released across the basolateral cell surface. ATP may, in fact, be released but "trapped" between the cell monolayer and the filter support and/or the detection reagent may not gain sufficient access to this "trapped" space. Therefore, only apical-directed ATP release was studied exclusively in the detection experiments below. Regardless of the filter support used to form cell monolayers and the amount of detection reagent included in the real-time experiments, basal or unstimulated or constitutive ATP release was low and not different between the panels of mutant and rescued cell monolayers studied. There was agreement between all mutant clones and all genetically rescued clones in all protocols below. As such, the data are pooled for mutant cell monolayers and rescued cell monolayers. Basal ATP release data are summarized in the bar graph in Fig. 1 as bioluminescence in arbitrary light units (ALU). In total, the amounts of ATP released were below $50 \mathrm{nM}$. A standard curve was run with each series of ATP release experiments. Thus, basal ATP secretion is not different across the apical membrane of mutant and rescued cell monolayers and the amount of ATP released is barely sufficient to engage the most sensitive $\mathrm{P} 2 \mathrm{Y}$ or $\mathrm{P} 2 \mathrm{X}$ cell surface receptors.
Ionomycin-stimulated ATP release is more robust in rescued versus mutant cell monolayers We first assessed the effect of an increase in intracellular free calcium $\left(\mathrm{Ca}^{2+}\right)$ on ATP release. This first study was done in part because of the emerging role of the primary central monocilium in mediating $\mathrm{Ca}^{2+}$ transients, sparks, and waves in cell monolayers derived from extracellular and intracellular stores [17-30]. This cilium-derived $\mathrm{Ca}^{2+}$ signal is triggered by touch or flow across this organelle and is mediated, at least in part, by the polycystin proteins, PC-1 and PC-2 [17-30]. Polycystin-2 is a part of the TRPP subfamily of TRP genes and is a distant relative of the transient receptor potential or TRPC gene family of $\mathrm{Ca}^{2+}$ entry channels [1730]. Ionomycin $(2 \mu \mathrm{M})$ applied to the apical surface of well-polarized cell monolayers triggered a slow, monophasic rise in ATP release over 3-5 min (see typical time courses below in Figs. 6 and 8). This response was a similar phenotype to that observed in previous studies by our laboratory in human vascular endothelial cell monolayers [37]. In mutant monolayers deficient in monocilia, an increase in cell $\mathrm{Ca}^{2+}$ increased extracellular ATP from below $50 \mathrm{nM}$ to $0.4 \mu \mathrm{M}$. Figure 2 shows data as bioluminescence in arbitrary light units (ALU) with corresponding estimated ATP for each step of the protocol based upon parallel standard curves with known amounts of ATP. In sharp contrast, rescued monolayers responded to ionomycin stimulation with a rise in secreted ATP from approximately $50 \mathrm{nM}$ to $2 \mu \mathrm{M}$, three- to fivefold higher sustained amounts on average than in mutant monolayers. The data in Fig. 2 also group the data from the panels of mutant and rescued clones which were in agreement. Taken together, these data show that cell $\mathrm{Ca}^{2+}$-stimulated ATP release is more robust when a well-formed central monocilium is present. In fact, the "releasable" pool of ATP that is sensitive to $\mathrm{Ca}^{2+}$ appears intact in cilium-competent monolayers and deficient in cilium-deficient monolayers.

Hypotonicity-induced ATP release is more robust in rescued versus mutant cell monolayers Hypotonic challenge and resultant cell swelling and regulatory volume decrease (RVD), a shared mechanism of cell volume regulation by all cells [41-44], is a robust stimulus for ATP release [4146]. It is a shared sentiment by most that ATP release precedes and triggers, at least in part, RVD mechanisms such as opening of parallel $\mathrm{K}^{+}$and $\mathrm{Cl}^{-}$channels to mediate rapid $\mathrm{KCl}$ efflux and to lower cell volume back to basal levels [41-46]. As such, we used hypotonic challenge to assess ATP release in mutant cilium-deficient cell monolayers versus rescued cilium-competent cell monolayers. Figure 3 summarizes these data. These stimuli followed the ionomycin treatment. We show other typical real-time courses below when hypotonic challenge was performed in the absence of ionomycin (see Fig. 7). In all monolayers, 


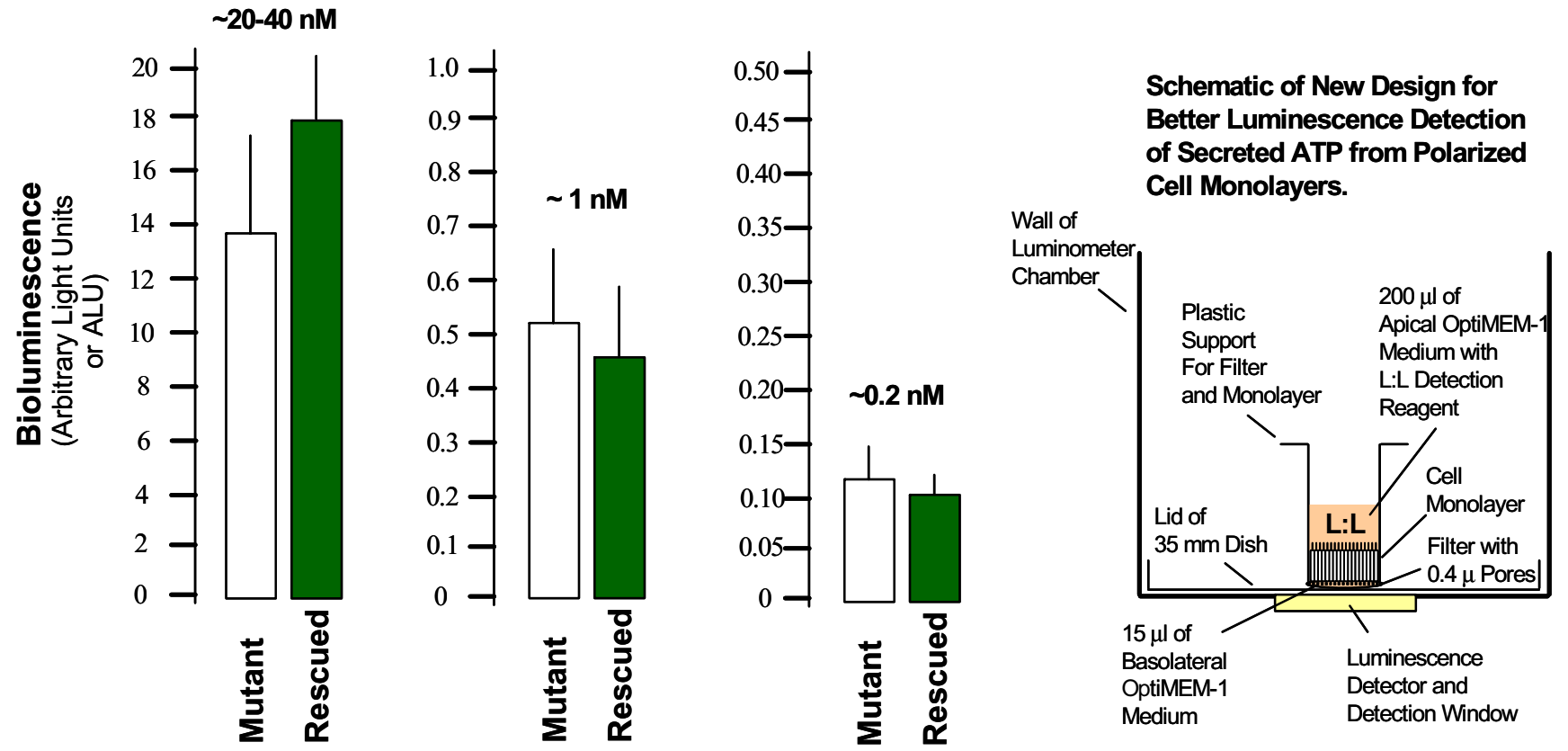

Fig. 1 Basal ATP release across the apical cell surface is not different between mutant cilium-deficient and genetically rescued ciliumcompetent orpk kidney cell monolayers. In three separate preparations of mutant versus rescued cell monolayers on different filter supports and exposed to different concentrations of luciferase:luciferin detection reagent, ATP release was not different between the ciliumdeficient and cilium-competent cell monolayers $(n=12$ for left set of bars; $n=6$ for center and right datasets). In this study, we had a breakthrough with regard to what filter support to use for our ATP release experiments studying cell monolayers on filter supports. We found that the $6.5-\mathrm{mm}$ diameter filter support (the same as used in open-circuit and Ussing chamber experiments studying ENaC upregulation [32]) was ideal for these real-time ATP release assays into the apical medium because the apical cell surface was as close as it could be and fully exposed to the luminescence detector in the base of the chamber. The left set of bars is data derived from this filter support and procedure. All other data in subsequent figures derive from this preparation. A diagram shows how the filter support was handled and placed into the luminometer chamber. After washing of serumcontaining medium away from the monolayer, a small volume of Opti-MEM 1 medium $(15 \mu \mathrm{l})$ is added in a drop to the lid of a $35-\mathrm{mm}$ dish to hydrate the preparation and to promote adherence to the lid of the dish; $200 \mu \mathrm{l}$ of Opti-MEM 1 medium containing $1 \mathrm{mg} / \mathrm{ml}$

hypotonic challenge of the apical surface $(50 \%$ dilution of the medium osmolality with distilled water containing $1 \mathrm{mg} / \mathrm{ml}$ detection reagent) triggered an increase in ATP release that had transient and sustained components. In mutant monolayers, hypotonic challenge increased ATP detected in the medium from approximately 0.4 to $3 \mu \mathrm{M}$ during the peak of stimulation and to a slightly lesser value at the end of the hypotonicity challenge phase. Addition of the same volume of isotonic medium (a "volume addition" control) increased ATP secretion slightly from 0.4 to $0.5 \mu \mathrm{M}$ (data not shown). Uniformly, rescued cilium-competent cell monolayers responded more vigorously to the hypotonic stimulus. This stimulus again followed the ionomycin treatment. ATP release increased from approximately 2 to lyophilized luciferase:luciferin reagent are placed within the cup in contact with the apical surface of the cell monolayer. Detection is then begun for bioluminescence due to secreted ATP from the cell monolayer into the apical space in continuous 15-s collection periods delayed only by the time to push the "start" button on the luminometer and to record the luminescence to an Excel spreadsheet. The standard curve with which approximations were made as to the secreted ATP concentrations was performed with each dataset, was compiled, and is as follows: $10^{-10} \mathrm{M}$ ATP, $0.052 \pm 0.005$ ALU... $10^{-9} \mathrm{M}$ ATP, $0.476 \pm$ 0.042 ALU...10 ${ }^{-8}$ M ATP, $4.95 \pm 0.51$ ALU...10 ${ }^{-7}$ M ATP, $51.2 \pm 4.8$ ALU...1 $10^{-6}$ M ATP, 455 \pm 23 ALU...10 $0^{-5}$ M ATP, 3956 \pm 311 ALU...10 $10^{-4} \mathrm{M}$ ATP and $10^{-3} \mathrm{M}$ ATP, $>9999$ ALU (exceeded limit of detection of luminometer). It is important to note that these are estimates of secreted ATP because we do not add inhibitors of ectoATPases and it is likely that our ATP release signal is diminished significantly by ATP degradation before detection. The left set of bars show basal ATP secretion from the $6.5-\mathrm{mm}$ diameter clear polyester filter support without feet that is immediately above the light sensor and bathed in $15 \mu \mathrm{l}$ of serosal medium. The middle set of bars show ATP secretion from a 12-mm polyester clear filter support with feet and bathed in $200 \mu \mathrm{l}$ of serosal medium. The third set of bars at right show ATP secretion from a polycarbonate filter support with feet and bathed in $200 \mu \mathrm{l}$ of serosal medium

5-10 $\mu \mathrm{M}$ at the peak of the response and to a lesser sustained level at the end of the hypotonic challenge phase. In volume addition control experiments, ATP release was triggered that was only transient and increased from 2 to $4 \mu \mathrm{M}$ on average (data not shown). Taken together, these data show that rescued cell monolayers respond more vigorously to hypotonic challenge than mutant cell monolayers with regard to ATP secretion, a signal required for cell volume regulation. Moreover, increases in cell $\mathrm{Ca}^{2+}$ prime swelling-induced ATP release and allow a larger ATP secretion signal to visualize.

Mechanically-induced ATP release is more robust in rescued versus mutant cell monolayers Harsh and fast pipetting of 


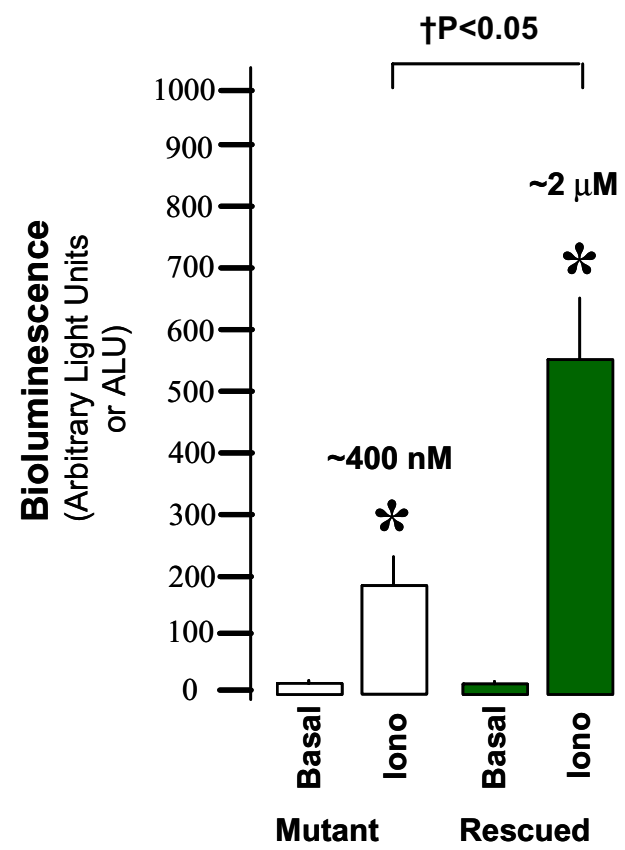

Fig. 2 Ionomycin-induced ATP release across the apical cell surface is markedly attenuated in mutant cilium-deficient versus genetically rescued cilium-competent orpk kidney cell monolayers. Six to nine cell monolayers were assessed at left for the summary data derived from the $6.5-\mathrm{mm}$ diameter filter support preparation. The fold difference in ionomycin $(2 \mu \mathrm{M}$, added in a $2-\mu \mathrm{l}$ bolus along the side of the plastic wall into the apical medium)-induced ATP release in rescued cell monolayers over mutant monolayers is graphed for the

\section{Rescued Cell Monolayers \\ Over Mutant Cell Monolayers}

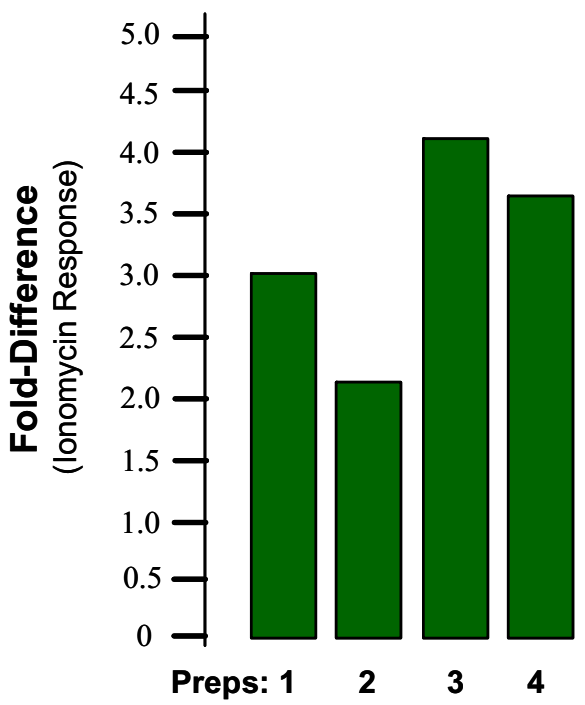

dataset at left along with three additional datasets. Although the filter supports, amount of detection reagent, and magnitude of luminescence measured differed between preparation to preparation ( $n=6$ each), the fold difference in the ionomycin effect was constant. The asterisk reflects $P<0.05$ by paired Student's $t$-test; the cross reflects $P<0.05$ significance by analysis of variance (ANOVA) and Tukey's ad hoc test. The statistical analysis and results are given similarly in all other figures

Fig. 3 Hypotonic cell swellinginduced ATP release across the apical cell surface is markedly attenuated in mutant ciliumdeficient versus genetically rescued cilium-competent orpk kidney cell monolayers. Cell monolayers were assessed at left for the summary data derived from the $6.5-\mathrm{mm}$ diameter filter support preparation. Hypotonic challenge was induced by adding an equal volume of distilled water ( $200 \mu \mathrm{l}$ with $1 \mathrm{mg} / \mathrm{ml} \mathrm{L}: \mathrm{L}$ reagent) down the wall of the apical chamber into the apical medium. The fold difference in three other preparations is graphed at right and was relatively constant again $(n=6-9)$. Statistics are shown like in Fig. 2

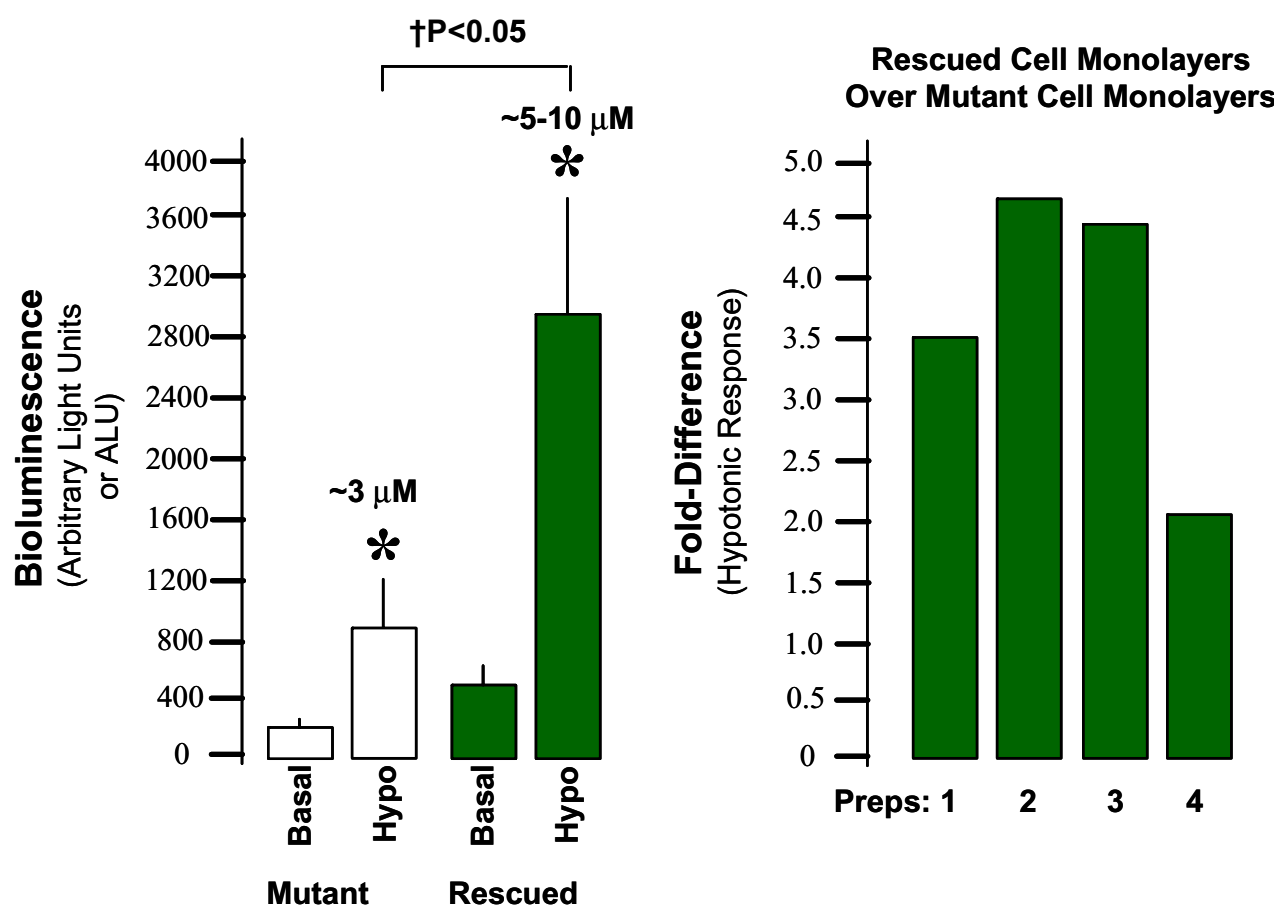


an $50 \mu \mathrm{l}$ volume of isotonic medium directly down on the center of the cilium-competent monolayers (the "mechanical stimulus") in three repetitions triggered an immediate ATP secretion that had transient and sustained phases like the swelling-induced ATP release from 2 to $3-4 \mu \mathrm{M}$ in rescued monolayers. This response was greatly attenuated in the mutant monolayers where ATP release was augmented only slightly from 0.4 to $0.5 \mu \mathrm{M}$. These experiments were performed after ionomycin challenge and the summary data are presented in Fig. 4b. In the absence of ionomycin pretreatment (Fig. 4a), mutant monolayers failed to respond to this stimulus altogether, whereas rescued monolayers responded significantly with an ATP release transient. Again, it is noted that increases in cell $\mathrm{Ca}^{2+}$ also appear to prime this mechanically sensitive ATP release mechanism. Taken together, these data suggest that the presence of a well-formed apical central monocilium is a

\section{a No lonomycin}

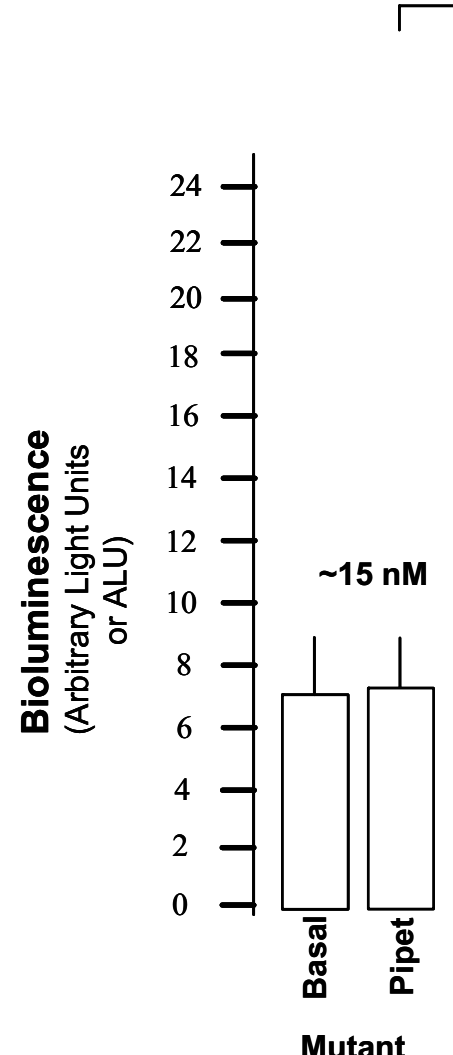

$+P<0.05$

$\mathscr{*}$

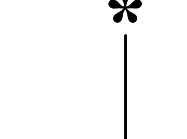

prerequisite for robust ATP secretion to provide a meaningful autocrine ATP signal on the luminal surface of cortical collecting duct principal cells.

Figures 5, 6, 7, and 8 provide typical real-time courses showing the luminescence data (in arbitrary light units) for mutant and rescued monolayers illustrating the summary data presented in Figs. 1, 2, 3, and 4. With the exception of basal ATP release, all phases of ATP secretion are markedly more robust in cilium-competent models versus cilium-deficient models across the apical cell surface. These data also revealed that there may be shared and different pools of "releasable" ATP within the cell. These data also began to reveal that increases in cell $\mathrm{Ca}^{2+}$ influence ATP secretion markedly.

An original physiological role for the apical central monocilium was that of a "mechanosensor." Figure 5

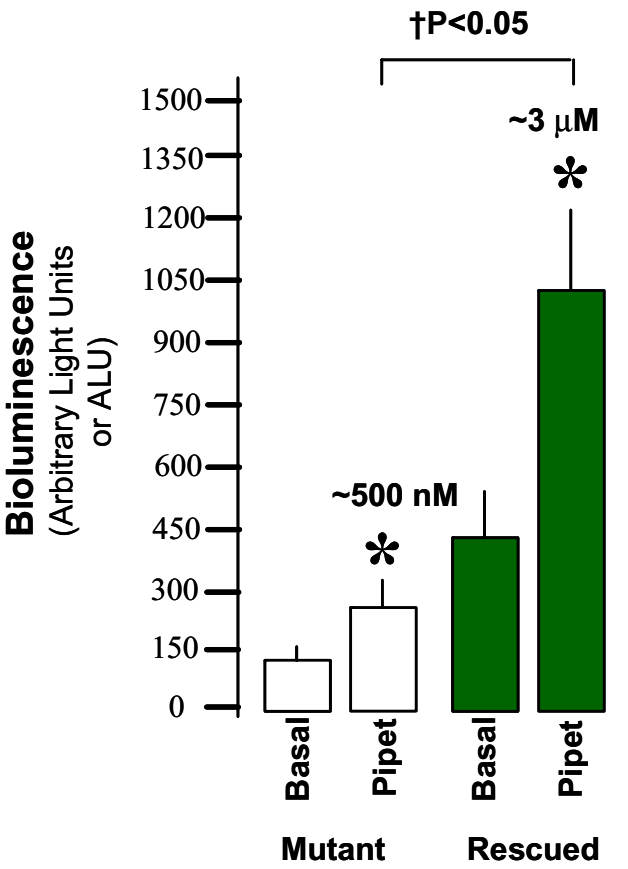

Fig. 4 Mechanically induced ATP release across the apical cell surface is markedly attenuated in mutant cilium-deficient versus genetically rescued cilium-competent orpk kidney cell monolayers. In a where no ionomycin pretreatment was performed, four mutant and four rescued cell monolayers were compared. In b where mechanical stimulation was performed after ionomycin challenge, six mutant and six rescued cell monolayers were compared. Without ionomycin, there was no response from the mutant cell monolayers. With ionomycin, there was a response from mutant monolayers that

was barely significant. In contrast, rescued cell monolayers responded robustly to the addition of $50 \mu$ of Opti-MEM 1 medium with detection reagent pipetted vigorously onto the center of the monolayer. In two additional repetitions, $50 \mu \mathrm{l}$ of apical medium was drawn up and ejected onto the center of the monolayer before luminescence readings continued. Figure 5 shows the nature of the response versus the hypotonic challenge and the ionomycin stimulation. Statistics are shown like in Fig. 2 
Fig. 5 Typical real-time course of mechanically induced ATP release across the apical cell surface in mutant versus rescued cell monolayers. In this and three subsequent figures, the green (closed or solid) balls reflect data from cilium-competent cell monolayers and the white (open) balls reflect data from ciliumdeficient cell monolayers. Lines do not connect the points because there are delays of a few seconds between readings. One can observe that there are clear ATP release transients induced in rescued cell monolayers by the mechanical insults. The signals observed from mutant cell monolayers are greatly attenuated

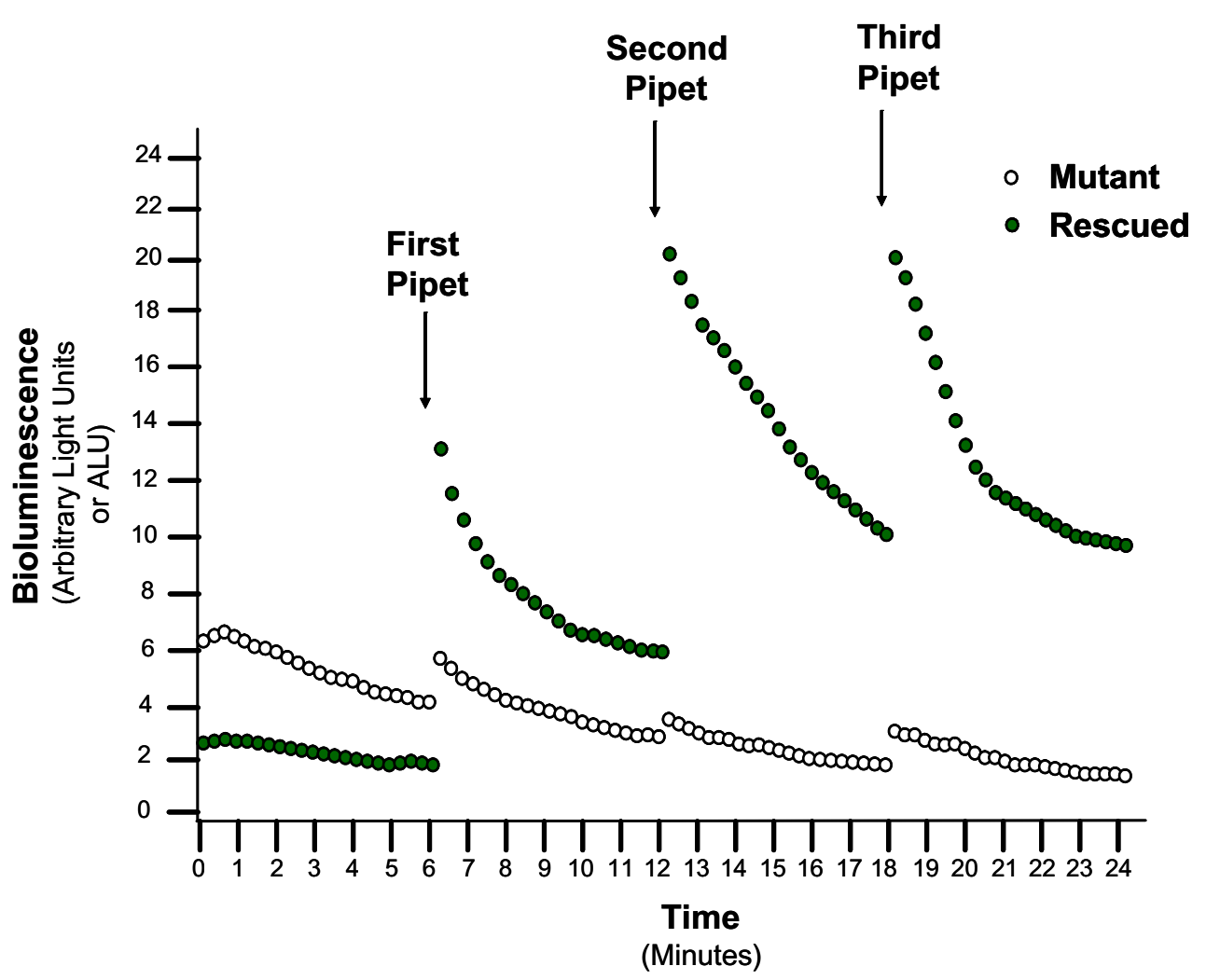

validates this idea using ATP secretion as the biological endpoint. Repeated pipetting of isotonic medium containing the same amount of detection reagent revealed repeated stimulation of ATP release transients in cilium-competent monolayers. The responses in mutant cilium-deficient cell monolayers were greatly attenuated. This comparison was performed on the same day with the same preparation of luciferase:luciferin detection reagent. Figure 6 shows a
Fig. 6 Typical real-time course of ionomycin and mechanically induced ATP release across the apical cell surface in mutant versus rescued cell monolayers. Ionomycin induces a slow monophasic sustained increase in ATP secretion that is three- to fivefold more robust in rescued cell monolayers. In the presence of ionomycin stimulation, the mechanical insults produce even more pronounced ATP secretion that is more sustained in nature when cell $\mathrm{Ca}^{2+}$ is elevated.

Nevertheless, the signals observed from mutant cell monolayers remain greatly attenuated

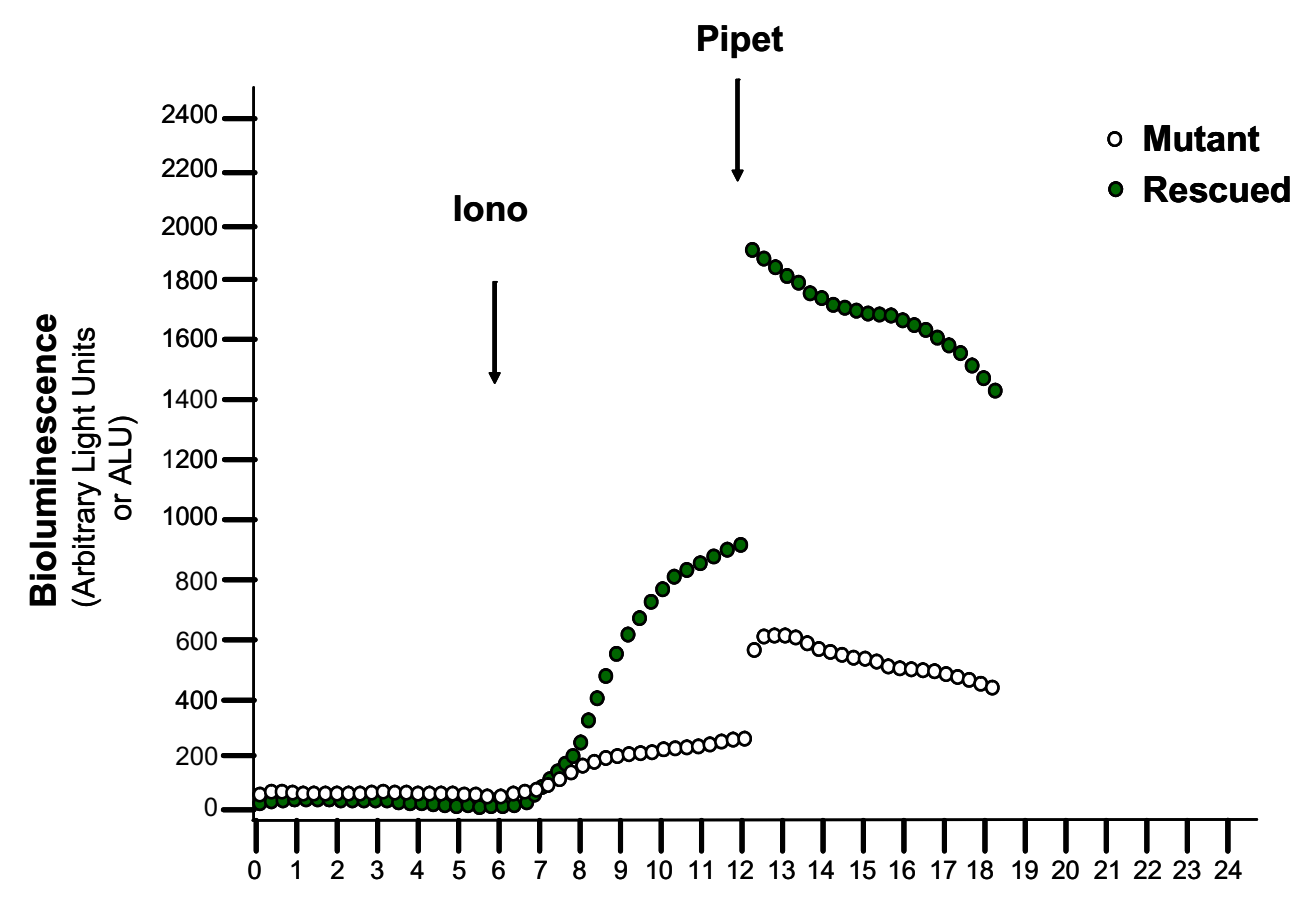

Time

(Minutes) 
similar experiment but with ionomycin pretreatment. Here, the classic ionomycin-induced ATP secretion phenotype is shown. It is a slow and monophasic increase in secreted ATP that is robust; however, the response of rescued monolayers is fourfold greater than mutant monolayers. Subsequent mechanical stimulation via repeated pipetting showed a more vigorous response in the cilium-competent monolayers versus the cilium-deficient monolayers. Figure 7 provides multiple compelling illustrations. First, the response to hypotonic challenge is shown and it is much more robust in rescued versus mutant cell monolayers. Interestingly, however, the repeated harsh pipetting stimulus is without effect in both rescued and mutant cells after the hypotonic challenge. In fact, the luminescence decreases modestly. These data suggest that these two mechanical stimuli may mobilize the same "releasable" pool of ATP. Figure 8 shows the relative effects of the three stimuli used in this study on rescued cilium-competent cell monolayers and on mutant cilium-deficient cell monolayers. Although greatly diminished because of the Y-axis scale, the mechanical stimulus triggered a fourfold greater ATP secretion transient in the rescued cell monolayers versus the mutant cell monolayers. Ionomycin also produced a fourfold greater sustained ATP release in rescued versus mutant monolayers. Hypotonic challenge also triggered a more robust response in the mutant cell monolayers. A large degree of the stimulated ATP release was inhibited by the broad specificity anion transport inhibitor, DIDS, suggesting that an ATP transport process may be mediating the release of ATP from intracellular pools. In the presence of DIDS inhibition, release is inhibited while degradation of released ATP proceeds unabated, leading to a sharp decline in the signal. In contrast, ionomycin-stimulated ATP release is attenuated by performing the luminescence experiment at $4^{\circ} \mathrm{C}$ (data not shown), suggesting a vesicular mechanism of release. Hexokinase is added at the end of every protocol to scavenge the ATP and abolish the luminescence signal.

Taken together, these data suggest that cell $\mathrm{Ca}^{2+}$ is critically important for priming the ATP release machinery. These data also suggest that the "releasable" pools of ATP are present in cilium-competent cell monolayers beneath the apical cell surface, while they may be impaired or

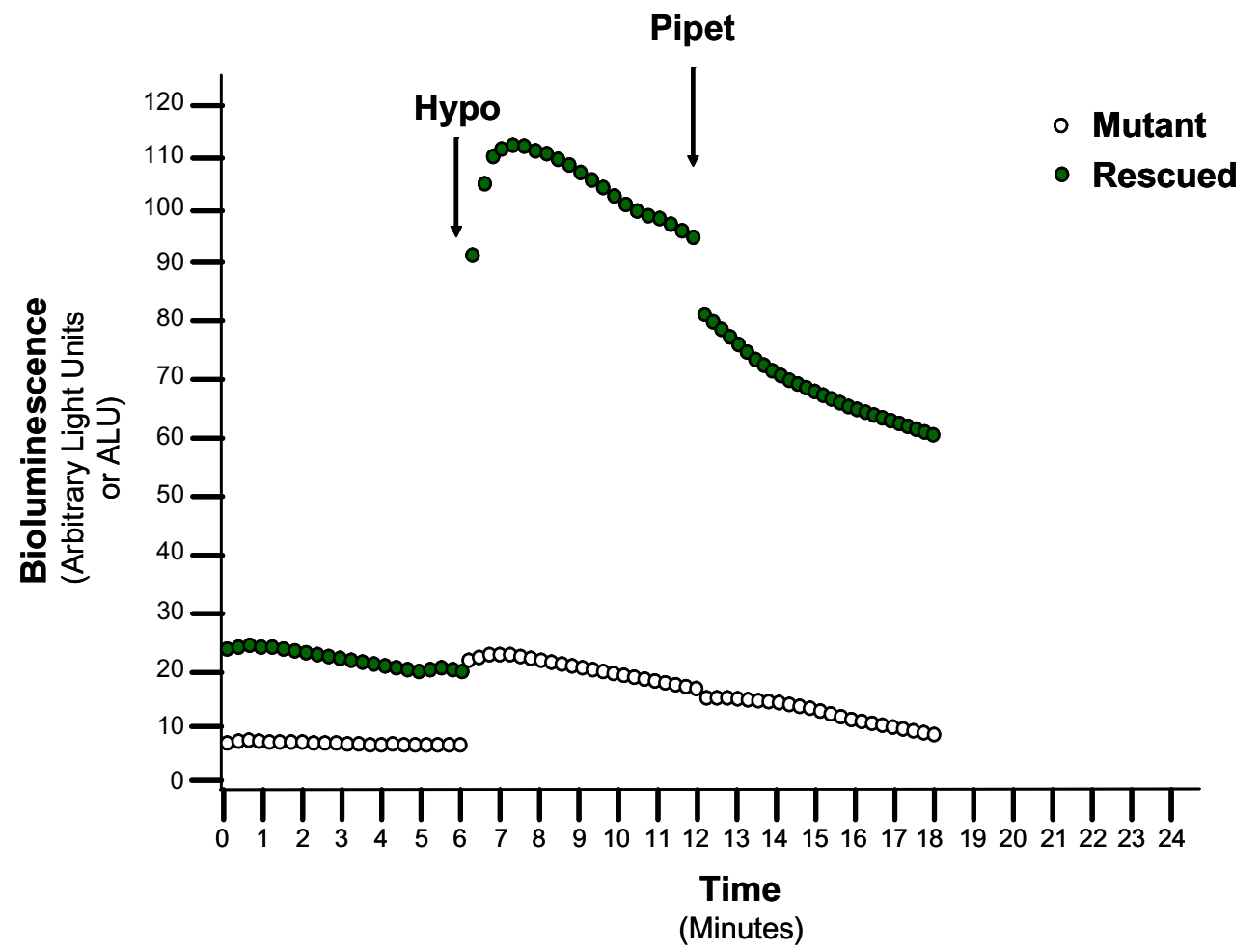

Fig. 7 Typical real-time course of hypotonic challenge-induced ATP release across the apical cell surface in mutant versus rescued cell monolayers. Hypotonicity induced a marked increase in ATP release that was fivefold more robust in rescued cell monolayers versus mutant cell monolayers. Of interest, however, mechanical stimulation via repeated pipetting near the center of the cell monolayers had no effect on ATP release after hypotonic cell swelling. These data suggest that both stimuli are indeed mechanical in nature and that the same pool of "releasable" ATP is being affected by each stimulus. The slight drop in signal with the pipetting stimulus is the addition of $50 \mu \mathrm{l}$ of isotonic medium to the $400 \mu \mathrm{l}$ of $50 \%$ diluted medium and the resultant change in osmotic strength at the apical cell surface. The hypotonicity-induced signal observed from mutant cell monolayers is again greatly attenuated 


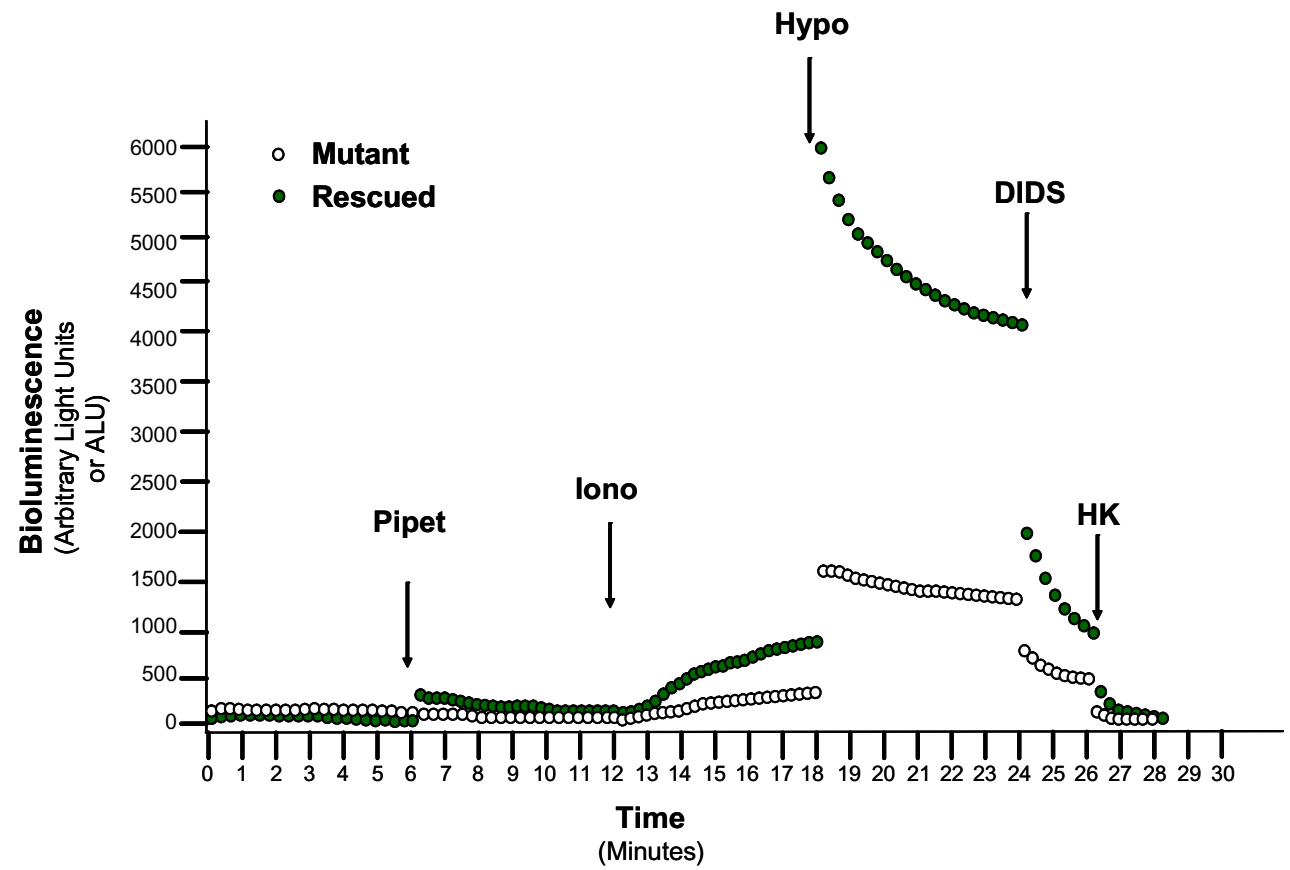

Fig. 8 Typical real-time course of all three stimuli given in an order where each stimulation can be observed in mutant versus rescued cell monolayers. Although the large scale diminished the mechanically induced signal and data, an ATP release transient is observed in rescued cell monolayers and not in mutant cell monolayers. The monophasic ionomycin response is then observed, again more robust in rescued cell monolayers. Then, hypotonic challenge is performed in the presence of ionomycin. Here, the largest values of secreted ATP

missing in cilium-deficient cell monolayers. These ideas will be revisited and discussed below.

Flow-induced calcium signals are attenuated in ciliumdeficient mutant monolayers versus cilium-competent monolayers An original physiological role for the apical central monocilium was that of a mediator of flow- or touch-induced $\mathrm{Ca}^{2+}$ signals in MDCK cells by Praetorius and Spring [17-19]. Subsequent studies in heterologous cells, renal collecting duct cell models, and renal collecting ducts showed that an intact cilium is required for the flowinduced $\mathrm{Ca}^{2+}$ signal [20-30]. To be faithful to a polarized epithelial cell monolayer system used routinely for this study and other studies [32, 34-40], we devised a flow chamber where the apical versus basolateral sides of the monolayer could be perfused independently and at different flow rates. The 12-mm diameter Snapwell transwell filter can then be inserted into this chamber for selective perfusion and fluorescence imaging. With a constant low rate of perfusion of the basolateral surface of the monolayers, low versus high rates of perfusion were performed on the apical surface in rescued versus mutant monolayers.

Figure 9 shows the response to modifications in saline $\mathrm{Na}$ and $\mathrm{Mg}$ and to high flow $(5 \mathrm{ml} / \mathrm{min})$ versus low flow are observed that approach $\sim 15-20 \mu \mathrm{M}$ in the apical medium bathing cilium-competent cell monolayers. In these plots, the effects of the broad specificity anion transport inhibitor, DIDS, are shown. DIDS diminishes ATP release in both types of monolayers and in other epithelial cell monolayer preparations to different degrees. The inhibition is partial and DIDS does not affect the detection reagent. Hexokinase is added at the end of each experiment to eliminate secreted ATP and to diminish the luminescence signal to low levels

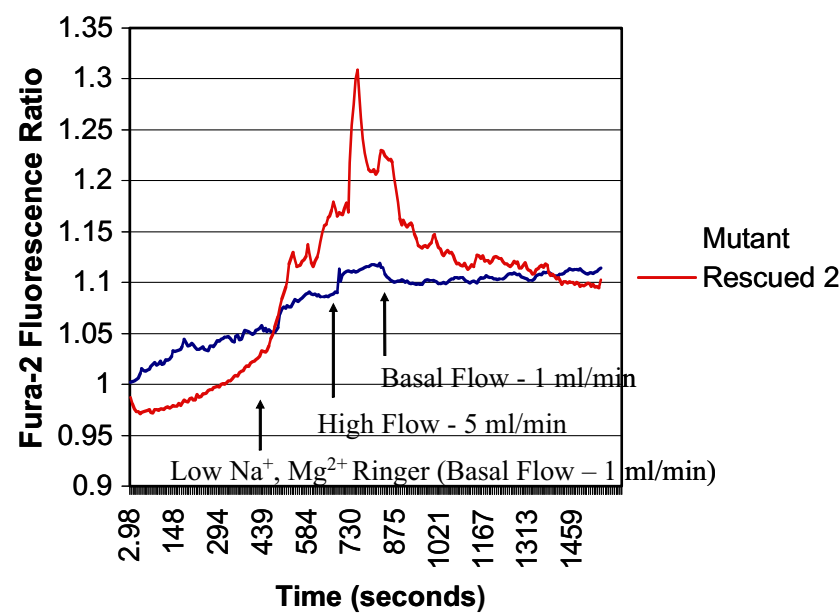

Fig. 9 Typical real-time courses of flow-induced $\mathrm{Ca}^{2+}$ transient signals across the apical cell surface in mutant versus rescued cell monolayers. Fluorescence ratio values were shown for Fura-2. It was very difficult to perform ionomycin-based calibrations to derive real cytosolic free $\mathrm{Ca}^{2+}$ values in this monolayer preparation that could be trusted. Moreover, the ionomycin used contaminated the perfusion lines for subsequent experiments. The flow-induced responses are observed in the center of each trace and the flow effect was reversed by returning to low flow. The use of the low $\mathrm{Na}^{+}$, low $\mathrm{Mg}^{2+}$ Ringer allowed us to view this transient more easily; it was more robust and long-lived under these ionic conditions where the $\mathrm{Ca}^{2+}$ entry channel inhibitors, $\mathrm{Na}^{+}$and $\mathrm{Mg}^{2+}$, were minimized 
( $1 \mathrm{ml} / \mathrm{min}$ ). When $\mathrm{Na}$ and $\mathrm{Mg}$ are lowered to mimic the amount left in collecting duct tubular fluid after the bulk of each cation is reabsorbed along the nephron (10 and $0.1 \mathrm{mM}$, respectively), an increase in cell $\mathrm{Ca}^{2+}$ is observed that is due to $\mathrm{Ca}^{2+}$ entry from extracellular stores. The modifications in extracellular saline have augmented $\mathrm{Ca}^{2+}$ entry and cytosolic free $\mathrm{Ca}^{2+}$ in previous experience [39, $40,47] . \mathrm{Ca}^{2+}$ competes with $\mathrm{Na}^{+}$through all $\mathrm{Ca}^{2+}$ entry channels that are, by definition, $\mathrm{Ca}^{2+}$-permeable nonselective cation channels $[39,40,47] . \mathrm{Mg}^{2+}$ blocks or impedes the pore of many different $\mathrm{Ca}^{2+}$ entry channels $[39,40,47]$. The response was greater in cilium-competent cell monolayers versus cilium-deficient cell monolayers to this $\mathrm{Na}^{+}$ and $\mathrm{Mg}^{2+}$ removal. When flow is increased, a flow-induced calcium signal is observed in cilium-competent monolayers that is reminiscent of such signals seen in isolated perfused renal collecting duct [20] and in other systems [21-29]. In cilium-deficient monolayers, this signal is present but impaired markedly. Taken together, these data show that cilium-competent cell monolayers are more able to respond to flow stimuli than cilium-deficient cell monolayers.

Summary data are also shown in Fig. 10 that shows the responses under different saline conditions alone and responses to high flow in different conditions. Several nuances emerge from these data that agree with previous work in which our laboratory and our collaborators have been involved [20,38]. It is important to note that our main intent was not to reproduce previously published data but to link cilium-derived $\mathrm{Ca}^{2+}$ signals to ATP secretion studied above. First, basal cell $\mathrm{Ca}^{2+}$ is indeed significantly higher in mutant cells versus rescued cells in this monolayer imaging preparation (Fig. 10a). These results agree with those performed by another collaborator in a study by Siroky et al. [38]. Second and curiously, however, the basal cell $\mathrm{Ca}^{2+}$ phenotype switches in experiments performed in the absence of extracellular $\mathrm{Ca}^{2+}$ (Fig. 10b). In nominally $\mathrm{Ca}^{2}$ ${ }^{+}$-free solutions, mutant cell $\mathrm{Ca}^{2+}$ is driven quite low, while rescued cell $\mathrm{Ca}^{2+}$ is maintained if not slightly augmented. These data with regard to resting cell $\mathrm{Ca}^{2+}$ indeed suggest that $\mathrm{Ca}^{2+}$ entry under basal or unstimulated conditions is actually heightened in mutant cell monolayers versus rescued cell monolayers due to a deregulated $\mathrm{Ca}^{2+}$ entry pathway [38]. A valid explanation for the reversal in phenotype under $\mathrm{Ca}^{2+}$-free conditions may result from the loss of ER cisternae immediately beneath apical central monocilia, causing mutant cell $\mathrm{Ca}^{2+}$ to decrease markedly under these conditions. In contrast, cilium-competent monolayers may have robust intracellular $\mathrm{Ca}^{2+}$ stores tied immediately beneath the monocilia to maintain basal cell $\mathrm{Ca}^{2+}$ in the absence of $\mathrm{Ca}^{2+}$ entry.

In the presence of extracellular $\mathrm{Ca}^{2+}$, modification of the Ringer to mimic collecting duct tubular fluid and to disinhibit $\mathrm{Ca}^{2+}$ entry channels augmented cell $\mathrm{Ca}^{2+}$ signifi- cantly only in cilium-competent cell monolayers (Fig. 10a). A change in the flow rate from $1 \mathrm{ml} / \mathrm{min}$ to $5 \mathrm{ml} / \mathrm{min}$ again only augmented cell $\mathrm{Ca}^{2+}$ in the form of a brief $\mathrm{Ca}^{2+}$ transient with a "spike" and a "shoulder" (Fig. 10a). A typical phenotype is shown in Fig. 9. Mutant cell monolayers failed to respond to flow with a significant change in cell $\mathrm{Ca}^{2+}$ (Fig. 9 shows the typical degree of response to flow). In the absence of extracellular $\mathrm{Ca}^{2+}$, the same magnitude and type of $\mathrm{Ca}^{2+}$ entry "spike" was observed in rescued cilium-competent cell monolayers (Fig. 10b). However, the sustained "shoulder" of this response was missing in the absence of extracellular $\mathrm{Ca}^{2+}$. Any response from the mutant cell monolayers was insignificant and sluggish. In this light, the rescued cell monolayers showed a complete reversal when flow was slowed; however, the mutant cell monolayers did not. The reason for this lack of reversal is unclear, but we speculate that the cells can no longer "sense" flow and, therefore, display deregulation with regard to cell $\mathrm{Ca}^{2+}$ in this manner as well. In Fig. 10c, responses in the rescued cell monolayers were assessed in the presence of apical gadolinium chloride, a broad spectrum inhibitor of mechanosensitive ion channels and $\mathrm{Ca}^{2+}$ entry channels [30, 38]. Infusion of gadolinium chloride during the course of the apical perfusion in the presence of extracellular calcium and in low and high flow also quieted the flow-induced calcium signal (Fig. 10c). The rise in cell $\mathrm{Ca}^{2+}$ in response to the reduction of $\mathrm{Na}^{+}$and $\mathrm{Mg}^{2+}$ was not blocked, suggesting that this $\mathrm{Ca}^{2+}$ entry mechanism is insensitive to gadolinium. These data suggest that a mechanosensitive $\mathrm{Ca}^{2+}$ entry channel is sensitive to gadolinium and plays a role in flow-induced $\mathrm{Ca}^{2+}$ entry. These data agree with the literature [17-30].

Many studies, however, have also implicated autocrine and paracrine purinergic signaling as a major player in mechanically induced $\mathrm{Ca}^{2+}$ sparks and waves in monolayer and tissue preparations [33, 48-54]. Indeed, in immature and mature MDCK cells lacking or bearing monocilia, a pressure pulse-induced $\mathrm{Ca}^{2+}$ signal was observed in each preparation and the signal was abolished by antagonists to purinergic signaling [33]. To test whether cilium-conferred autocrine ATP release and signaling was important for the cilium-dependent $\mathrm{Ca}^{2+}$ signal, we performed a similar apical flow protocol in the presence of the ATPase/ADPase, apyrase (Fig. 10c). Apyrase blocked the flow-induced $\mathrm{Ca}^{2+}$ signal. Apyrase also attenuated the rise in cell $\mathrm{Ca}^{2+}$ induced by lowering apical $\mathrm{Na}^{+}$and $\mathrm{Mg}^{2+}$. Taken together, these data suggest that an autocrine ATP signal, released by the monolayer itself, contributes directly to the flow-induced and cilium-derived $\mathrm{Ca}^{2+}$ signal. With the more robust stimulated ATP release phenotypes and the flow-induced $\mathrm{Ca}^{2+}$ signals in the rescued monolayers versus mutant monolayers, we speculate that each may require the apical central monocilium as an integrating sensory organelle. 
a

Presence of Extracellular Calcium

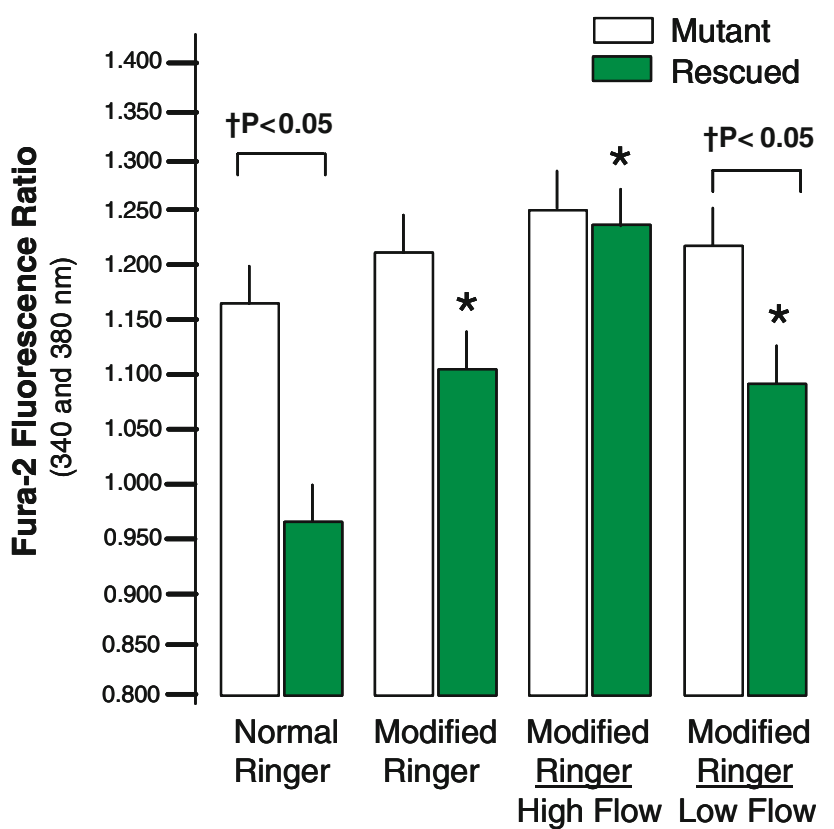

C

Extracellular Calcium $\underline{0 \text { Extracellular Calcium }}$
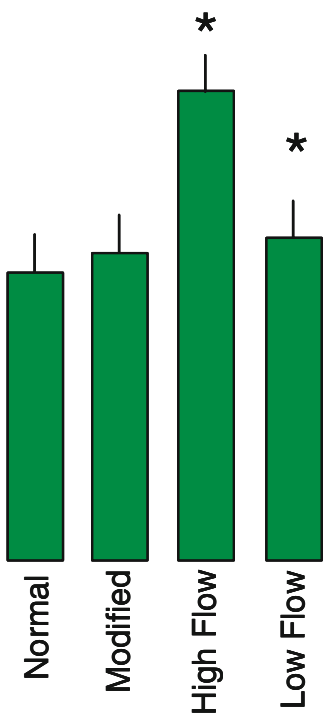

b

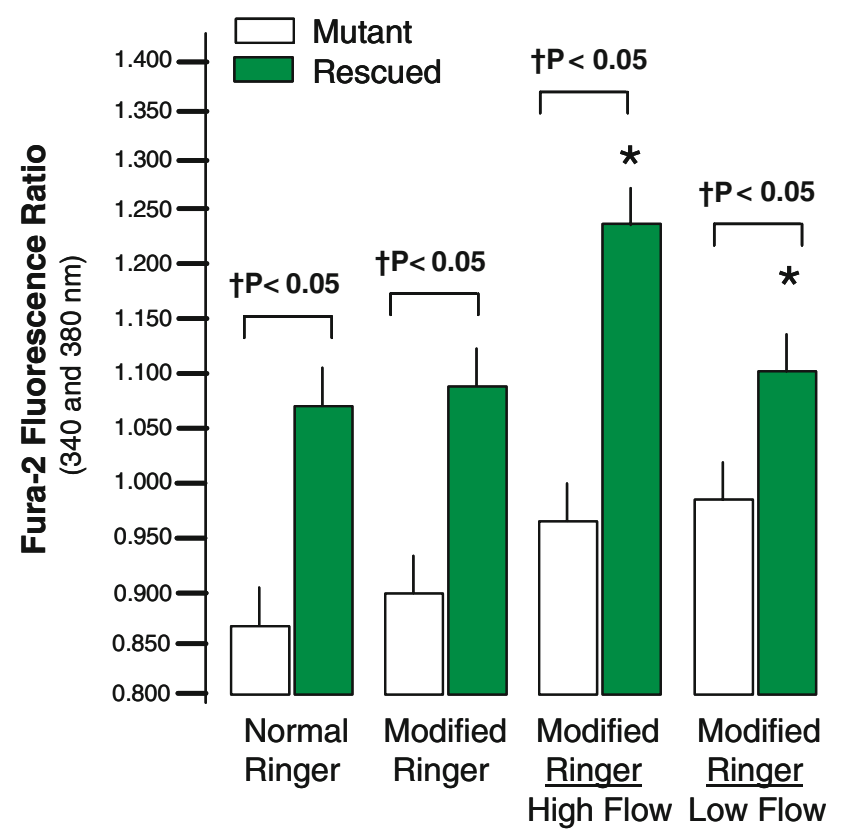

Extracellular Calcium

Extracellular Calcium

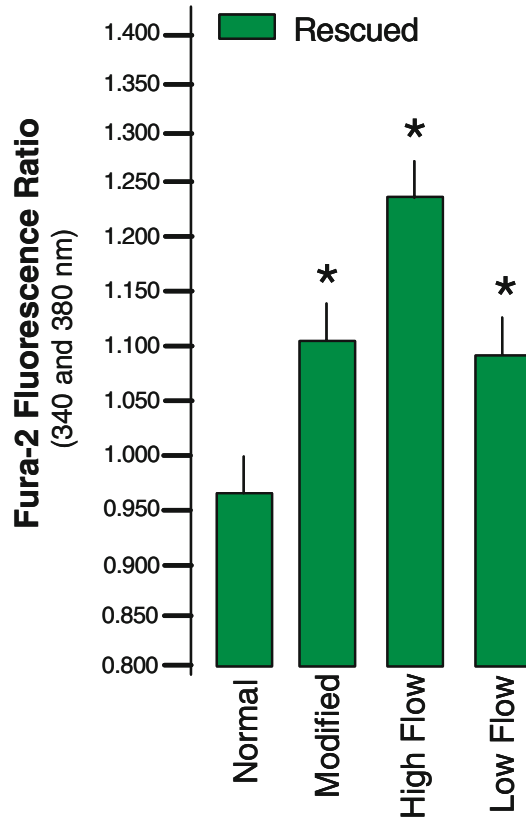

+ Gadolinium Chloride

+ Apyrase Scavenger
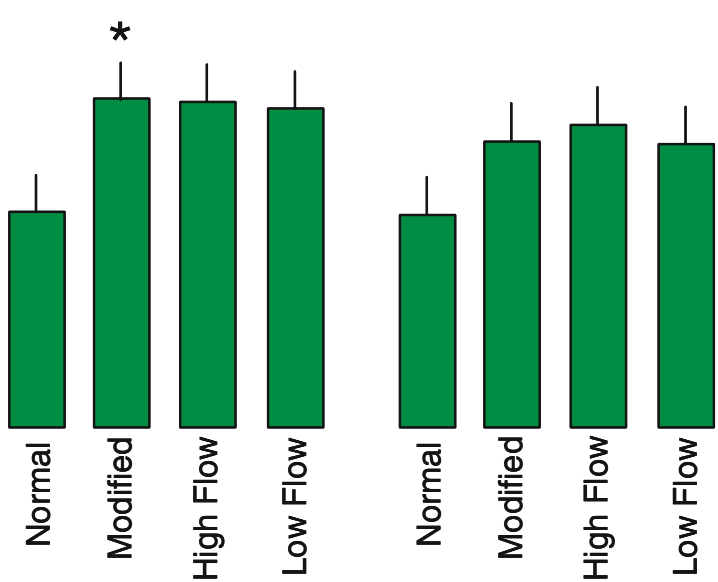

Fig. 10 Summary data under different experimental conditions for flow-induced $\mathrm{Ca}^{2+}$ transient signals across the apical cell surface in mutant versus rescued cell monolayers: requirement for autocrine secreted nucleotides. a Summary data from the experiments shown in Fig. 9. b Responses to flow in the absence of extracellular calcium. A flow-induced $\mathrm{Ca}^{2+}$ signal is still present in the cilium-competent cell monolayers. It is as robust in the peak values of $\mathrm{Ca}^{2+}$ increase (the tip of the spike is used for the summary data); however, the shoulder is absent from the transient in the absence of extracellular $\mathrm{Ca}^{2+}$. In the cilium-deficient cell monolayers, there is a slow increase in $\mathrm{Ca}^{2+}$ that

is not significant and appears unrelated to flow. The asterisks in a and b refer to a $P<0.05$ significant change from the previous stage of the experiment by paired Student's $t$-test. The crosses show significant difference by ANOVA between mutant and rescued cell monolayer $\mathrm{Ca}^{2+}$ levels. c The asterisks refer to a $P<0.05$ significant change from the previous stage of the experiment by paired Student's $t$-test. Only data from rescued cell monolayers are shown where the $\mathrm{Ca}^{2+}$ signal is much more robust. Gadolinium and apyrase blocked the flow-induced $\mathrm{Ca}^{2+}$ transient signal, suggesting that $\mathrm{Ca}^{2+}$ entry channels and an autocrine extracellular ATP signal are required to observe the $\mathrm{Ca}^{2+}$ signal 
Fig. 11 Working model: the monocilium is required for a mature ATP secretion apparatus at the apical cell surface and both the monocilium and an autocrine ATP signal are required for flow-induced $\mathrm{Ca}^{2+}$ signals

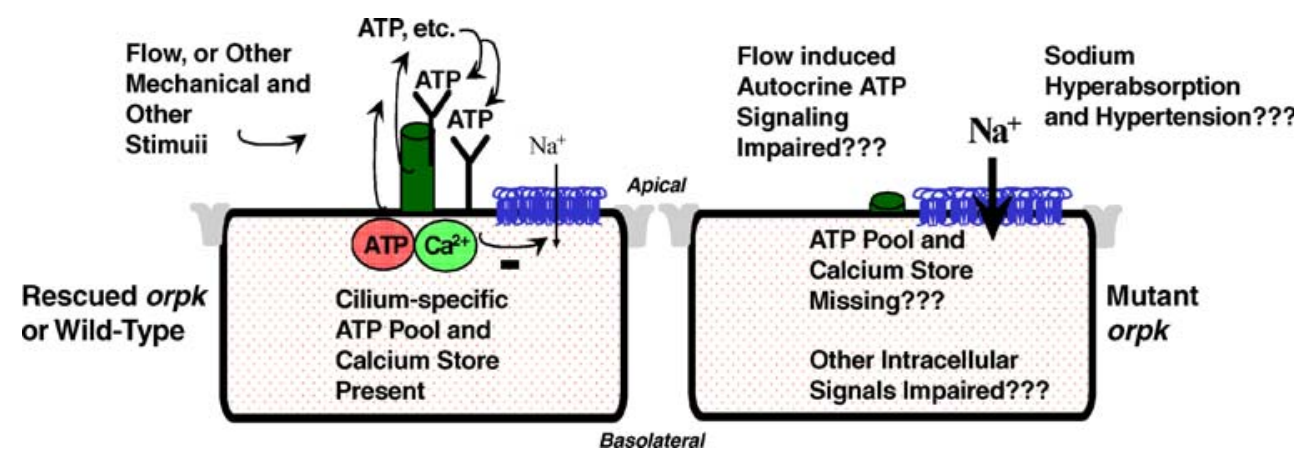

\section{Discussion}

Figure 11 provides a cartoon that illustrates our current working hypothesis concerning the requirement of an autocrine ATP signal for monocilium-specific signaling. Our data suggest that the secreted ATP near the apical surface of principal cells of the renal collecting duct with well-formed monocilia is robust enough to engage cell surface P2X receptor channels or P2Y G protein-coupled receptors. In cilium-deficient mutant cell monolayers, the amount of ATP secreted under basal conditions or in response to stimuli may be insufficient. $\mathrm{P} 2 \mathrm{Y}$ and $\mathrm{P} 2 \mathrm{X}$ receptors may be present on or near the monocilium to transduce this autocrine ATP signal. Recently, in a P2X $\mathrm{X}_{4}$ deficient mouse [55], flow- or shear stress-induced $\mathrm{Ca}^{2+}$ signals and resultant nitric oxide production were attenuated markedly in vascular endothelial cells versus wild-type controls. These transgenic mice also have blood pressure regulation problems [55]. Ando and colleagues had implicated ATP release and $\mathrm{P} 2 \mathrm{X}_{4}$ previously in endothelial cell $\mathrm{Ca}^{2+}$ entry signaling [56-58]. Our laboratory has emerging data that $\mathrm{P} 2 \mathrm{X}_{4}$ is expressed on the basal half or just beneath motile respiratory cilia in human respiratory tissues (L. Liang, Z. Bebok, and EM Schwiebert, unpublished observations). Silberberg and colleagues have long postulated that a "P2X cilia" is critical in mediating extracellular ATP regulation of ciliary beat in freshly isolated epithelial cells from airway and esophagus [5961]. Our laboratory has found that $\mathrm{P}_{2} \mathrm{X}_{4}, \mathrm{P}_{2} \mathrm{X}_{5}$, and $\mathrm{P} 2 \mathrm{X}_{6}$ have shared and robust expression in epithelia from the respiratory tract, gastrointestinal (GI) tract and renal system $[35,36]$, and from vascular endothelia from multiple blood vessels [37]. Work in progress is examining the expression of $\mathrm{P} 2 \mathrm{X}$ and $\mathrm{P} 2 \mathrm{Y}$ purinergic receptors on cilia.

As introduced, it is becoming abundantly clear that the monocilium in particular and cilia and flagella in general are sensory organelles [1-5]. In tissues where high flow is present (large airways, proximal tubule, arteries, arterioles, etc.), the monocilium or cilia may be flow sensors for the cell on which they are present. In tissues where low flow is present (bile duct, pancreatic duct, renal collecting duct, small airways, capillaries, venules, veins, etc.), the monocilium may be a chemosensor or an osmosensor. Our data suggest that it may both influence ATP secretion as well as be a chemosensor for the secreted ATP. Arguably, secreted nucleotides and nucleosides are most potent in a local microenvironment within a cellular or tissue microenvironment. Burnstock and colleagues have described this concept elegantly in past review where they described purinergic signaling as being potent and essential in the lumen of tubules and ducts of kidney and gut $[62,63]$. A semiclosed system such as the lumen of a renal tubule or duct is ideal in this regard.

Along these lines, the effect of changes in flow has been studied extensively and elegantly. Touch, flow, shear stress, and cell swelling are potent regulators of ion transport [64-67]. $\mathrm{Ca}^{2+}$ entry as well as $\mathrm{Na}^{+}, \mathrm{K}^{+}$, and $\mathrm{Cl}^{-}$transport are governed by mechanical stimuli [17-30, 64-67]. Mechanical stimuli are also well-known to trigger ATP release in many cell and tissue systems [48-54, 68]. The propagation of $\mathrm{Ca}^{2+}$ sparks and waves triggered by mechanical stimuli are thought to be mediated by at least two cellular mechanisms: (1) $\mathrm{Ca}^{2+}$-permeable gap junctions that link the cells together and (2) paracrine extracellular purinergic signaling that allows cells to communicate in a local environment [68]. In fact, our data show that an increase in cell $\mathrm{Ca}^{2+}$ primes the "releasable" pools of ATP that are mobilized by hypotonic cell swelling and other mechanical stimuli. However, one can still observe both pipetting- and hypotonicity-induced ATP release without ionomycin pretreatment that is more robust in ciliumcompetent versus cilium-deficient cell monolayers. Moreover, we also found that we could not observe a mechanically induced ATP release signal after hypotonic cell swelling. This finding suggests that these two "mechanical" stimuli (albeit different) affect the same pool of releasable ATP. Unfortunately, we still need better tools to define each ATP release mechanism and pool. However, our work with low temperature inhibition of vesicle traffic and inhibition of anion transport properties with the broad specificity inhibitor, DIDS, suggests that both ATP transport mechanisms and exocytosis of ATP-filled vesicles contribute to 
secreted ATP phenotypes (EM Schwiebert et al., unpublished observations).

Recently, we found that $\mathrm{ENaC}$-mediated $\mathrm{Na}^{+}$absorption is upregulated markedly in cilium-deficient CCD PC monolayers derived from the $T g 737^{\text {orpk }}$ mouse [32]. Of many hypotheses put forward to explain this pathophysiological phenotype, one prominent postulate was that the malformed cilium caused the loss of key inhibitory signals that are normally cilium-derived that limit ENaC activity. Indeed, in several different cellular systems, there is agreement that purinergic signaling inhibits $\mathrm{ENaC}$ function [69-74]. Modulation of purinergic receptor-driven cell $\mathrm{Ca}^{2+}$ signaling may be a future putative therapeutic target (along with $\mathrm{ENaC}$ itself) to control hypertension that occurs in the majority of human ARPKD patients, especially the children that escape respiratory insufficiency soon after birth [6].

Finally, it is our hope that this work connects the seemingly disparate conclusions of Satlin and coworkers [20] and those of Leipziger, Praetorius, and colleagues [33]. Taken together, our data suggest that a well-formed monocilium central to the apical membrane of a collecting duct principal cell is essential for a mature ATP secretion apparatus. One could conceive of this apparatus as a wellformed pool of ATP poised to be secreted in response to different stimuli or the appropriate presence of ATP release machinery (ATP-filled vesicles and/or ATP transport mechanisms). Our studies also suggest that the cilium-derived $\mathrm{Ca}^{2+}$ transient, induced by flow in our study or by other modes in other studies, requires an underlying autocrine ATP signal that is likely transduced by P2X and P2Y ATP receptors on or near the monocilium. Without a well-formed cilium at the apical surface, autocrine purinergic signaling, cilium-derived signaling, and modulation of downstream effectors become disrupted.

Acknowledgments We acknowledge the support and assistance of Elisabeth Welty, our laboratory manager, in this work. We acknowledge the support of R01 DK067343 to EMS, R01 DK055007 to BKY, R21 DK071007 to PDB, and the P30 Recessive PKD Research and Translation Core Centers (DK074038). We acknowledge the support of the Department of Physiology and Biophysics for the stipend and benefits for $\mathrm{MBH}$.

\section{References}

1. Davenport JR, Yoder BK (2005) An incredible decade for the primary cilium: a look at a once-forgotten organelle. Am J Physiol Renal Physiol 289(6):F1159-F1165

2. Zhang Q, Taulman PD, Yoder BK (2004) Cystic kidney disease: all roads lead to the cilium. Physiology (Bethesda) 19:225-230

3. Pazour GJ (2004) Intraflagellar transport and cilia-dependent renal disease: the ciliary hypothesis of polycystic kidney disease. J Am Soc Nephrol 15(10):2528-2536

4. Pazour GJ, Rosenbaum JR (2002) Intraflagellar transport and cilia-dependent diseases. Trends Cell Biol 12(12):551-555
5. Nauli SM, Zhou J (2004) Polycystins and mechanosensation in renal and nodal cilia. Bioessays 26(8):844-856

6. Guay-Woodford LM, Desmond RA (2003) Autosomal recessive polycystic kidney disease: the clinical experience in North America. Pediatrics 111(5):1072-1080

7. Guay-Woodford LM (2003) Murine models of polycystic kidney disease: molecular and therapeutic insights. Am J Physiol Renal Physiol 285:F1034-F1049

8. Grantham JJ (2001) Polycystic kidney disease: from the bedside to the gene and back. Curr Opin Nephrol Hypertens 10(4):533-542

9. Wilson PD (2002) The genes and proteins associated with polycystic kidney diseases. Minerva Urol Nefrol 54(4):201-211

10. Wilson PD (1997) Epithelial cell polarity and disease. Am J Physiol 272(4):F434-F442

11. Wilson PD (2001) Polycystin: new aspects of structure, function, and regulation. J Am Soc Nephrol 12(4):834-845

12. Harris PC (2002) Molecular basis of polycystic kidney disease: PKD1, PKD2, and PKHD1. Curr Opin Nephrol Hypertens 11 (3):309-314

13. Sutters M, Germino GG (2003) Autosomal dominant polycystic kidney disease: molecular genetics and pathophysiology. J Lab Clin Med 141(2):91-101

14. Wu G, Somlo S (2000) Molecular genetics and mechanism of autosomal dominant polycystic kidney disease. Mol Genet Metab 69(1):1-15

15. Haycraft CJ, Swoboda P, Taulman PD, Thomas JH, Yoder BK (2001) The C. elegans homolog of the murine cystic kidney disease gene $\operatorname{Tg} 737$ functions in a ciliogenic pathway and is disrupted in osm-5 mutant worms. Development 128:1493-1505

16. Winkelbauer ME, Schafer JC, Haycraft CJ, Swoboda P, Yoder BK (2005) The C. elegans homologs of nephrocystin-1 and nephrocystin-4 are cilia transition zone proteins involved in chemosensory perception. J Cell Sci 118:5575-5587

17. Praetorius HA, Frokiaer J, Nielsen S, Spring KR (2003) Bending the primary cilium opens calcium-sensitive intermediate conductance potassium channels in MDCK cells. J Membr Biol 191:193200

18. Praetorius HA, KR Spring (2001) Bending the MDCK cell primary cilium increases intracellular calcium. J Membr Biol $184: 71-79$

19. Praetorius HA, Spring KR (2003) Removal of the MDCK cell primary cilium abolishes flow sensing. J Membr Biol 191:69-76

20. Liu W, Murcia NS, Duan Y, Weinbaum S, Yoder BK, Schwiebert EM, Satlin LM (2004) Mechanoregulation of intracellular $\mathrm{Ca}^{2+}$ concentration is attenuated in collecting duct of monociliumimpaired orpk mice. Am J Physiol Renal Physiol 289:F978-F988

21. Nauli SM, Rossetti S, Kolb RJ et al (2006) Loss of polycystin-1 in human cyst-lining epithelia leads to ciliary dysfunction. J Am Soc Nephrol 17(4):1015-1025

22. Hanaoka K, Qian F, Boletta A, Bhunia AK, Piontek K, Tsiokas L, Sukhatme VP, Guggino WB, Germino GG (2000) Co-assembly of polycystin-1 and polycystin-2 produces unique cation-permeable currents. Nature 408(6815):990-994

23. Koulen P, Cai Y, Geng L, Maeda Y, Nishimura S, Witzgall R, Ehrlich BE, Somlo S (2002) Polycystin-2 is an intracellular calcium release channel. Nat Cell Biol 4(3):191-197

24. Gonzalez-Perret S, Kim K, Ibarra C, Damiano AE, Zotta E, Batelli M, Harris PC, Reisin IL, Arnaout MA, Cantiello HF (2001) Polycystin-2, the protein mutated in autosomal dominant polycystic kidney disease (ADPKD), is a Ca2+-permeable nonselective cation channel. Proc Natl Acad Sci U S A 98(3):1182-1187

25. Luo Y, Vassilev PM, Li X, Kawanabe Y, Zhou J (2003) Native polycystin-2 functions as a plasma membrane calcium-permeable cation channel in renal epithelia. Mol Cell Biol 23(7):2600-2607

26. Vassilev PM, Guo L, Chen XZ et al (2001) Polycystin-2 is a novel cation channel implicated in defective intracellular $\mathrm{Ca}(2+)$ homeo- 
stasis in polycystic kidney disease. Biochem Biophys Res Comm 282(1):341-350

27. Nauli SM, Alenghat FJ, Luo Y et al (2003) Polycystins 1 and 2 mediate mechanosensation in the primary cilium of kidney cells. Nat Genet 33(2):129-137

28. Chen XZ, Vassilev PM, Basora N et al (1999) Polycystin-L is a calcium-regulated cation channel permeable to calcium ions. Nature 401(6751):383-386

29. Liu Y, Li Q, Tan M, Zhang YY, Karpinski E, Zhou J, Chen XZ (2002) Modulation of the human polycystin-L channel by voltage and divalent cations. FEBS Lett 525(1-3):71-76

30. Minke B, Cook B (2002) TRP channel proteins and signal transduction. Physiol Rev 82:429-472

31. Madsen KM, Tisher CC (1986) Structural-functional relationship along the distal nephron. Am J Physiol 250:F1-F15

32. Olteanu D, Yoder BK, Liu W et al (2006) Heightened epithelial $\mathrm{Na}+$ channel-mediated $\mathrm{Na}+$ absorption in a murine polycystic kidney disease model epithelium lacking apical monocilia. Am J Physiol Cell Physiol 290:C952-C963

33. Praetorius HA, Frokiaer J, Leipziger J (2005) Transepithelial pressure pulses induce nucleotide release in polarized MDCK cells. Am J Physiol Renal Physiol 288:F133-F141

34. Taylor AL, Kudlow BA, Marrs KL, Gruenert DC, Guggino WB, Schwiebert EM (1998) Bioluminescence detection of ATP release mechanisms in epithelia. Am J Physiol 275:C1391-C1406

35. Taylor AL, Schwiebert LM, Smith JJ, King C, Jones JR, Sorscher EJ, Schwiebert EM (1999) Epithelial P2X purinergic receptor channel expression and function. J Clin Invest 104:875-884

36. Schwiebert EM, Wallace DP, Braunstein GM, King SR, PetiPeterdi J, Hanaoka K, Guggino WB, Guay-Woodford LM, Bell PD, Sullivan LS, Grantham JJ, Taylor AL (2002) Autocrine extracellular purinergic signaling in epithelial cells derived from polycystic kidneys. Am J Physiol Renal Physiol 282:F763-F775

37. Schwiebert LM, Rice WC, Kudlow BA, Taylor AL, Schwiebert EM (2002) Extracellular ATP signaling and P2X purinergic receptor channels in primary human vascular endothelial cells. Am J Physiol Cell Physiol 282(2):C289-C301

38. Siroky BJ, Ferguson WB, Fuson AL, Xie Y, Fintha A, Komlosi P, Yoder BK, Schwiebert EM, Guay-Woodford LM, Bell PD (2006) Loss of primary cilia results in deregulated and unabated apical calcium entry in ARPKD collecting duct cells. Am J Physiol Renal Physiol 290:F1320-1328

39. Zsembery A, Boyce AT, Liang L, Peti-Peterdi J, Bell PD, Schwiebert EM (2003) Sustained calcium entry through P2X nucleotide receptor channels in human airway epithelial cells. J Biol Chem 278:13398-13408

40. Zsembery A, Fortenberry JA, Liang L, Bebok Z, Tucker TA, Boyce AT, Braunstein GM, Welty EA, Bell PD, Sorscher EJ, Clancy JP, Schwiebert EM (2004) Extracellular zinc and ATP restore chloride secretion across cystic fibrosis airway epithelia by triggering calcium entry. J Biol Chem 279:10720-10729

41. Braunstein GM, Zsembery A, Tucker TA, Schwiebert EM (2004) Purinergic signaling underlies CFTR control of human airway epithelial cell volume. J Cyst Fibros 3(2):99-117

42. Braunstein GM, Roman RM, Clancy JP et al (2001) Cystic fibrosis transmembrane conductance regulator facilitates ATP release by stimulating a separate ATP release channel for autocrine control of cell volume regulation. J Biol Chem 276(9):6621-6630

43. Roman RM, Lomri N, Braunstein GM, Feranchak AP, Simeoni L, Davison AK, Mechetner EB, Schwiebert EM, Fitz JG (2001) Evidence for multidrug resistance-1 P-glycoprotein-dependent regulation of cellular ATP permeability. J Membr Biol 183(3): $165-173$

44. Gatof D, Kilic G, Fitz JG (2004) Vesicular exocytosis contributes to volume-sensitive ATP release in biliary cells. Am J Physiol Gastrointest Liver Physiol 286:G538-G546
45. Roman RM, Wang Y, Lidofsky SD, Feranchak AP, Lomri N, Scharschmidt BF, Fitz JG (1997) Hepatocellular ATP-binding cassette protein expression enhances ATP release and autocrine regulation of cell volume. J Biol Chem 272:21970-21976

46. Boudreault F, Grygorczyk R (2004) Cell swelling-induced ATP release is tightly dependent on intracellular calcium elevations. J Physiol 561:499-513

47. Zsembery A, Schwiebert EM (2006) Methods and compositions for P2X receptor calcium entry channels and other calcium entry mechanisms. United States Utility Patent Application No. 10/ 542,555 Pending

48. Sauer H, Heschler J, Wartenberg M (2000) Mechanical straininduced $\mathrm{Ca} 2+$ waves are propagated via ATP release and purinergic receptor activation. Am J Physiol Cell Physiol 279: C295-C307

49. Frame MK, de Feijter AW (1997) Propagation of mechanically induced intercellular calcium waves via gap junctions and ATP receptors in rat liver epithelial cells. Exp Cell Res 230:197-207

50. Wang Y, Roman R, Lidofsky SD, Fitz JG (1996) Autocrine signaling through ATP release represents a novel mechanism for cell volume regulation. Proc Natl Acad Sci U S A 93:12020-12025

51. Lewis SA, Lewis JR (2006) Kinetics of urothelial ATP release. Am J Physiol Renal Physiol 291:F332-F340

52. Maroto R, Hamill O (2001) Brefeldin A block of integrindependent mechanosensitive ATP release from Xenopus oocytes reveals a novel mechanism of mechanotransduction. J Biol Chem 276:23867-23872

53. Genetos DC, Geist DJ, Liu D, Donahue HJ, Duncan RL (2005) Fluid shear-induced ATP secretion mediates prostaglandin release in MC3T3-E1 osteoblasts. J Bone Miner Res 20:41-49

54. Sun Y, Chai TC (2006) Augmented extracellular ATP signaling in bladder urothelial cells from patients with interstitial cystitis. Am J Physiol Cell Physiol 290:C27-C34

55. Yamamoto K, Sokabe T, Matsumoto T et al (2005) Impaired flowdependent control of vascular tone and remodeling in P2X4deficient mice. Nat Med 12:133-137

56. Yamamoto K, Sokabe T, Ohura N, Nakatsuka H, Kamiya A, Ando J (2003) Endogenously released ATP mediates shear stress-induced $\mathrm{Ca} 2+$ influx into pulmonary artery endothelial cells. Am J Physiol Heart Circ Physiol 285:H793-H803

57. Yamamoto K, Korenaga R, Kamiya A, Ando J (2000) Fluid shear stress activates calcium influx into human endothelial cells via P2X4 purinoceptors. Circ Res 87:385-391

58. Yamamoto K, Korenaga R, Kamiya A, Qi Z, Sokabe M, Ando J (2000) P2X4 receptors mediate ATP-induced calcium influx in human vascular endothelial cells. Am J Physiol Heart Circ Physiol 279:H285-H292

59. Ma W, Korngreen A, Weil S, Cohen EB, Priel A, Kuzin L, Silberberg SD (2006) Pore properties and pharmacological features of the P2X receptor channel in airway ciliated cells. J Physiol 571:503-517

60. Ma W, Korngreen A, Uzlaner N, Priel Z, Silberberg SD (1999) Extracellular sodium regulates airway ciliary motility by inhibiting a P2X receptor. Nature 400:894-897

61. Korngreen A, Ma W, Priel Z, Silberberg SD (1998) Extracellular ATP directly gates a cation-selective channel in rabbit airway ciliated epithelial cells. J Physiol 508:703-720

62. Unwin RJ, Bailey MA, Burnstock G (2003) Purinergic signaling along the renal tubule: the current state of play. News Physiol Sci $18: 237-241$

63. Giaroni C, Knight GE, Ruan HZ, Glass R, Bardini M, Lecchini S, Frigo G, Burnstock G (2002) P2 receptors in the murine gastrointestinal tract. Neuropharmacology 43:1313-1323

64. Satlin LM, Sheng S, Woda CB, Kleyman TR (2001) Epithelial $\mathrm{Na}^{+}$channels are regulated by flow. Am J Physiol Renal Physiol 280(6):F1010-F1018 
65. Woda CB, Bragin A, Kleyman TR, Satlin LM (2001) Flowdependent $\mathrm{K}^{+}$secretion in the cortical collecting duct is mediated by a maxi $\mathrm{K}^{+}$channel. Am J Physiol Renal Physiol 280(5):F786F793

66. Woda CB, Leite M Jr, Rohatgi R, Satlin LM (2002) Effects of luminal flow and nucleotides on cytosolic calcium in rabbit cortical collecting duct. Am J Physiol Renal Physiol 283:F437F446

67. Schwiebert EM, Mills JW, Stanton BA (1994) Actin-based cytoskeleton regulates a chloride channel and cell volume in a renal cortical collecting duct cell line. J Biol Chem 269:70817089

68. Schwiebert EM (2000) Extracellular ATP-mediated propagation of calcium waves. Focus on "mechanical strain-induced $\mathrm{Ca}(2+)$ waves are propagated via ATP release and purinergic receptor activation.” Am J Physiol Cell Physiol 279:C281-C283

69. McCoy DE, Taylor AL, Kudlow BA, Karlson KH, Slattery MJ, Schwiebert LM, Schwiebert EM, Stanton BA (1999) Nucleotides regulate $\mathrm{NaCl}$ transport across mIMCD-K2 cells via $\mathrm{P} 2 \mathrm{X}$ and $\mathrm{P} 2 \mathrm{Y}$ purinergic receptors. Am J Physiol 277:F552-F559

70. Schwiebert EM, Liang L, Cheng NL, Olteanu D, Williams CL, Welty EA, Zsembery A (2005) Extracellular ATP- and zinc-gated P2X receptor calcium entry channels: physiological sensors and therapeutic targets. Purinergic Signalling 1(4):299-310

71. Schwiebert EM, Zsembery A (2003) Extracellular ATP as a signaling molecule for epithelial cells. Biochim Biophys Acta 1615:7-32

72. Schwiebert EM, Kishore BK (2001) Extracellular purinergic signaling along the renal epithelium. Am J Physiol Renal Physiol 280:F945-F963

73. Schwiebert EM (2001) ATP release mechanisms, ATP receptors, and purinergic regulation along the nephron. Clin Exp Pharmacol Physiol 28:340-350

74. Ma H, Ling BN (1996) Luminal adenosine receptors regulate amiloride-sensitive $\mathrm{Na}^{+}$channels in A6 distal nephron cells. Am J Physiol 270:F798-F805 